\title{
System Bi-Sr-O: Synergistic measurements of thermodynamic properties using oxide and fluoride solid electrolytes
}

\author{
K. T. Jacob ${ }^{\text {a) }}$ and K. P. Jayadevan \\ Materials Research Centre and Department of Metallurgy, Indian Institute of Science, \\ Bangalore 560 012, India
}

(Received 5 May 1997; accepted 10 November 1997)

Phase equilibrium and electrochemical studies of the ternary system $\mathrm{Bi}-\mathrm{Sr}-\mathrm{O}$ indicate the presence of six ternary oxides $\left(\mathrm{Bi}_{2} \mathrm{SrO}_{4}, \mathrm{Bi}_{2} \mathrm{Sr}_{2} \mathrm{O}_{5}, \mathrm{Bi}_{2} \mathrm{Sr}_{3} \mathrm{O}_{6}, \mathrm{Bi}_{4} \mathrm{Sr}_{6} \mathrm{O}_{15}, \mathrm{Bi}_{14} \mathrm{Sr}_{24} \mathrm{O}_{52}\right.$, and $\left.\mathrm{Bi}_{2} \mathrm{Sr}_{6} \mathrm{O}_{11}\right)$ and three solid solutions $(\delta, \beta$, and $\gamma)$. An isothermal section of the phase diagram is established at $1050 \mathrm{~K}$ by phase analysis of quenched samples. Three compounds, $\mathrm{Bi}_{4} \mathrm{Sr}_{6} \mathrm{O}_{15}, \mathrm{Bi}_{14} \mathrm{Sr}_{24} \mathrm{O}_{52}$, and $\mathrm{Bi}_{2} \mathrm{Sr}_{6} \mathrm{O}_{11}$, contain $\mathrm{Bi}^{5+}$ ions. The stability of these phases is a function of oxygen partial pressure. The chemical potentials of $\mathrm{SrO}$ in two-phase fields are determined as a function of temperature using solid-state cells based on single crystal $\mathrm{SrF}_{2}$ as the electrolyte. Measurement of the emf of cells based on $\mathrm{SrF}_{2}$ as a function of oxygen partial pressure in the gas at constant temperature gives information on oxygen content of the compounds present at the electrodes. The chemical potentials of $\mathrm{Bi}_{2} \mathrm{O}_{3}$ in two-phase fields of the pseudobinary $\mathrm{Bi}_{2} \mathrm{O}_{3}-\mathrm{SrO}$ are measured using cells incorporating $\left(\mathrm{Y}_{2} \mathrm{O}_{3}\right) \mathrm{ZrO}_{2}$ as the solid electrolyte. The standard free energies of formation of the ternary oxides are calculated independently using emfs of different cells. The independent assessments agree closely; the maximum difference in the value of $\Delta G_{f}^{\circ}\left(\mathrm{Bi}_{2 m} \operatorname{Sr}_{n} \mathrm{O}_{p}\right) /(m+n)$ is $\pm 350 \mathrm{~J} / \mathrm{mol}$ of component binary oxides. The results are discussed in the light of the phase diagram and compared with calorimetric and chemical potential measurements reported in the literature. The combined use of emf data from cells incorporating fluoride and oxide electrolytes enhances the reliability of derived data.

\section{INTRODUCTION}

As a part of the systematic studies on phase equilibria and thermodynamic properties of the quaternary system $\mathrm{Bi}-\mathrm{Ca}-\mathrm{Sr}-\mathrm{Cu}-\mathrm{O}$ which contains several superconducting oxides, measurements have been made on the ternary system $\mathrm{Bi}-\mathrm{Sr}-\mathrm{O}$. Phase diagrams provide indispensable guidelines for the control of impurity phases in the preparation of high $T_{c}$ oxides. Thermodynamic data on subsystems are fundamental inputs for computation of phase equilibria in a multicomponent oxide system as a function of temperature and partial pressure of oxygen. Because of their high oxygen-ion conductivity, $\mathrm{Bi}_{2} \mathrm{O}_{3}$ based solid solutions are also of interest as electrolytes for solid oxide fuel cells.

The phase diagram for the system $\mathrm{Bi}_{2} \mathrm{O}_{3}-\mathrm{SrO}$ has been investigated by a number of researchers. Guillermo et al. ${ }^{1}$ and Conflant et al. ${ }^{2}$ used high temperature x-ray diffraction (HTXRD) and differential thermal analysis (DTA) to establish phase relations in the pseudobinary system in air. The diagrams proposed are very similar and are probably based to a large extent on a common database. Conflant $e t a l^{2}$ have slightly altered the phase transition temperature of $\beta$-phase. Hence, only

\footnotetext{
${ }^{a}$ Address correspondence to this author.
}

the most recent paper $^{2}$ will be referred to in further discussions. Levin and Roth ${ }^{3}$ used HTXRD to study $\mathrm{Bi}_{2} \mathrm{O}_{3}$-rich solid solutions. XRD on quenched samples was employed by Roth et al., ${ }^{4}$ Hwang et al., ${ }^{5}$ and Vstavskaya et al. ${ }^{6}$ to map the phase diagram in air. Phase diagrams of Roth et al. ${ }^{4}$ and Hwang et al. ${ }^{5}$ also appear to be based on the same experimental information. DTA/TGA (thermogravimetric analysis) and XRD were employed by Abbattist et al. ${ }^{7}$ to study phase relations for SrO-rich compositions in pure $\mathrm{O}_{2}$, air, and silica ampules sealed under vacuum. Jacob and Mathews ${ }^{8}$ have investigated the ternary system $\mathrm{BiO}_{1.5}-\mathrm{SrO}-\mathrm{CuO}$ at $1123 \mathrm{~K}$ in pure $\mathrm{O}_{2}$ at ambient pressure. Slobodin et $a l .{ }^{9}$ have investigated the ternary system in the region $\mathrm{Bi}_{2} \mathrm{O}_{3} / \mathrm{SrO}>0.5$ in air at $1023 \mathrm{~K}$. Strictly, this diagram is a projection of phase relations in the ternary $\mathrm{Bi}_{2} \mathrm{O}_{3}-\mathrm{SrO}-\mathrm{O}\left(\mathrm{P}_{\mathrm{O}_{2}}=2.12 \times 10^{4} \mathrm{~Pa}\right)$ from the oxygen apex onto the $\mathrm{Bi}_{2} \mathrm{O}_{3}-\mathrm{SrO}$ isopleath. The diagram shows that the phases that will appear if compositions along the $\mathrm{Bi}_{2} \mathrm{O}_{3}-\mathrm{SrO}$ pseudobinary are equilibrated in air. Phase relations in the binary $\mathrm{Bi}_{2} \mathrm{O}_{3}-\mathrm{SrO}$ under the specified conditions can be obtained from these studies on the ternary system. A review of the reported ternary compounds indicates that several of these contain excess oxygen and do not lie on the $\mathrm{Bi}_{2} \mathrm{O}_{3}-\mathrm{SrO}$ join of the ternary system $\mathrm{Bi}-\mathrm{Sr}-\mathrm{O}$. Although there are 
some common features in the results obtained by various investigators, there are differences in the stability ranges of many phases. Among the important differences are the extended stability of $\beta$-phase and reduced stability of $\mathrm{Bi}_{2} \mathrm{SrO}_{4}$ in the phase diagram of Conflant et al. ${ }^{2}$ compared to that of Hwang et al. ${ }^{5}$ Normally, HTXRD used by the first group of researchers ${ }^{2}$ is more reliable for mapping high temperature phase relations than room temperature XRD of quenched samples employed by the second group. ${ }^{5}$ However, because of the volatility of $\mathrm{Bi}_{2} \mathrm{O}_{3}$, the sample composition can change during prolonged high temperature exposure unless special containment techniques are employed. ${ }^{8}$ More recent work by Vstavskaya et al. ${ }^{6}$ is in better agreement with the phase diagram proposed by Hwang et al. ${ }^{5}$ An evaluated "phase diagram" for the system $\mathrm{Bi}_{2} \mathrm{O}_{3}-\mathrm{SrO}$ in air is displayed in Fig. 1 to provide a focus for discussion. Strictly, this diagram is a projection of phase relations in the ternary $\mathrm{Bi}_{2} \mathrm{O}_{3}-\mathrm{SrO}-\mathrm{O}\left(\mathrm{P}_{\mathrm{O}_{2}}=2.12 \times 10^{4} \mathrm{~Pa}\right)$ from the oxygen apex onto the $\mathrm{Bi}_{2} \mathrm{O}_{3}-\mathrm{SrO}$ isopleath. The diagram shows the phases that will appear if compositions along the $\mathrm{Bi}_{2} \mathrm{O}_{3}-\mathrm{SrO}$ pseudobinary are equilibrated in air. Phase relations for $\mathrm{X}_{\mathrm{SrO}}>0.67$ are primarily based on the results of this study. Crystallographic information on the compounds is summarized in Table I.

The solubility of $\mathrm{SrO}$ in low temperature $\alpha-\mathrm{Bi}_{2} \mathrm{O}_{3}$ appears to be negligible. ${ }^{2} \mathrm{Hwang}$ et al..$^{5}$ indicate a small solubility of $\mathrm{SrO}$ in $\alpha-\mathrm{Bi}_{2} \mathrm{O}_{3}$, without experimental evidence. There is considerable solubility of $\mathrm{SrO}$ in $\delta-\mathrm{Bi}_{2} \mathrm{O}_{3},{ }^{1-5}$ but the solid solution range is less extensive

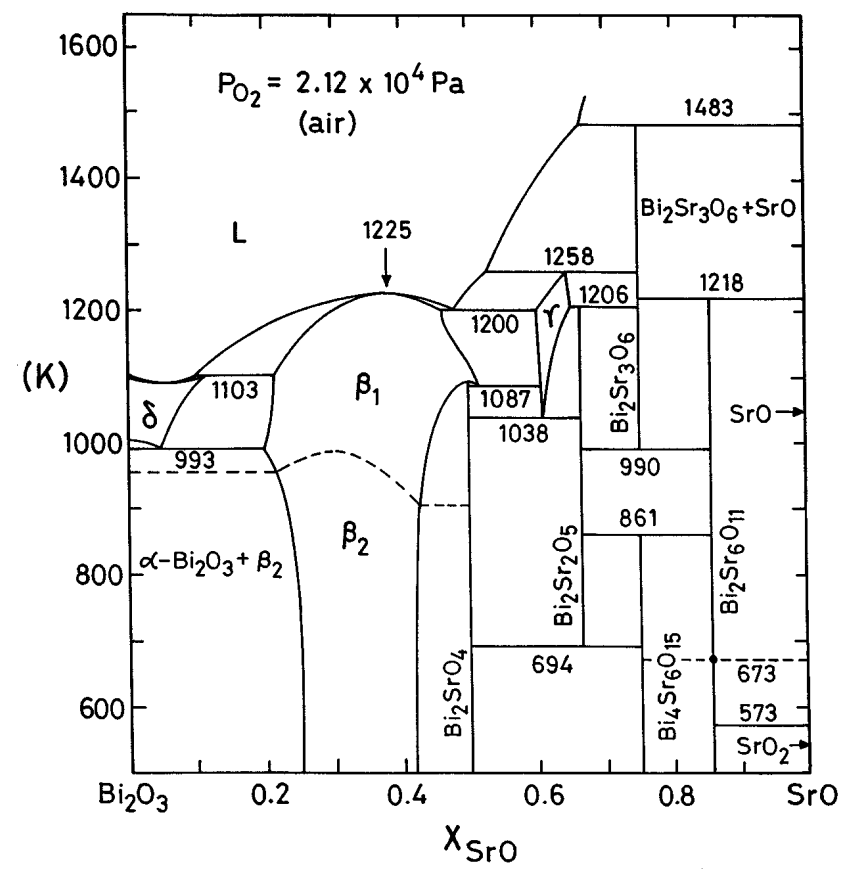

FIG. 1. Projection of phase relations in the system $\mathrm{Bi}_{2} \mathrm{O}_{3}-\mathrm{SrO}-\mathrm{O}$ in air onto the $\mathrm{Bi}_{2} \mathrm{O}_{3}-\mathrm{SrO}$ isopleath. than for the corresponding $\mathrm{Bi}_{2} \mathrm{O}_{3}-\mathrm{CaO}$ system. ${ }^{10}$ The $\beta$-phase with a rhombohedral unit cell extends from $\mathrm{X}_{\mathrm{SrO}} \approx 0.2$ to $\mathrm{X}_{\mathrm{SrO}} \approx 0.42$ at $1000 \mathrm{~K}^{5,6}$ and melts congruently at $1225 \mathrm{~K}^{5,6}$ The $\beta$-phase exists in two forms; the high temperature form $\beta_{1}$ is stable above 906 to $987 \mathrm{~K}$, depending on composition. ${ }^{2}$ The high temperature phase exhibits high oxygen ion conductivity, ${ }^{11}$ but cannot be retained at room temperature by quenching.

Conflant et al. ${ }^{2}$ found that the compound $\mathrm{Bi}_{2} \mathrm{SrO}_{4}$ decomposes to $\beta_{1}$ and $\gamma$ at $1053 \mathrm{~K}$ using HTXRD. According to Hwang et al., ${ }^{5}$ the compound $\mathrm{Bi}_{2} \mathrm{SrO}_{4}$ undergoes a phase transition to a high temperature form with slightly lower SrO content at $1098 \mathrm{~K}$. The high temperature form decomposes to liquid and $\gamma$-phase at $1213 \mathrm{~K}$. Zinkevich et al. ${ }^{12}$ report melting of stoichiometric $\mathrm{Bi}_{2} \mathrm{SrO}_{4}$ at $1214 \mathrm{~K}$. Jacob and Mathews ${ }^{8}$ identified the compound in samples quenched from $1123 \mathrm{~K}$. Vstavskaya et al. ${ }^{6}$ show the decomposition of $\mathrm{Bi}_{2} \mathrm{SrO}_{4}$ to $\beta$ and $\mathrm{Bi}_{2} \mathrm{Sr}_{2} \mathrm{O}_{5}$ at $1188 \mathrm{~K}$. Emf results obtained in this study suggest congruent transformation of $\mathrm{Bi}_{2} \mathrm{SrO}_{4}$ to $\beta_{1}$ solid solution. The rhombohedral solid solution $\left(\beta_{1}\right)$ cannot be quenched to room temperature without crystallization of $\mathrm{Bi}_{2} \mathrm{SrO}_{4}$. At higher temperatures the compound composition enters the two-phase field $\beta+$ $\gamma$. If $\mathrm{Bi}_{2} \mathrm{SrO}_{4}$ decomposed to $\beta_{1}$ and $\gamma$ as proposed by Conflant et al., ${ }^{2}$ it should have been possible to retain the high temperature two-phase structure by quenching. Figure 1 is based on the findings of Conflant et al. ${ }^{2}$ and results of this study, both of which are based on high-temperature measurements.

There is general agreement on the stability range of the $\gamma$-phase and the upper stability limit of $\mathrm{Bi}_{2} \mathrm{Sr}_{2} \mathrm{O}_{5}{ }^{2,5}$ The compound $\mathrm{Bi}_{2} \mathrm{Sr}_{2} \mathrm{O}_{5}$ decomposes to $\gamma$ and $\mathrm{Bi}_{2} \mathrm{Sr}_{3} \mathrm{O}_{6}$ at $1206 \mathrm{~K}$. The unit cell of $\mathrm{Bi}_{2} \mathrm{Sr}_{2} \mathrm{O}_{5}$ has orthorhombic symmetry, but there is variability in the reported space group. ${ }^{1,4,21}$ Torardi et al. ${ }^{21}$ found evidence for the existence of a superlattice along the $c$-direction in long exposure precession photographs of single crystals. They attributed the superlattice to the ordering of oxygen vacancies and the resultant replacement of $\mathrm{Bi}$ atoms. Conflant et al. ${ }^{2}$ suggest decomposition of the compound $\mathrm{Bi}_{2} \mathrm{Sr}_{2} \mathrm{O}_{5}$ to $\mathrm{Bi}_{2} \mathrm{SrO}_{4}$ and $\mathrm{SrO}$ at $913 \mathrm{~K}$. This is not supported by the studies of Abbattista et al. ${ }^{7}$ who show the presence of two other stable phases $\mathrm{Bi}_{4} \mathrm{Sr}_{6} \mathrm{O}_{15}$ and $\mathrm{Bi}_{2} \mathrm{Sr}_{6} \mathrm{O}_{11}$ between $\mathrm{Bi}_{2} \mathrm{Sr}_{2} \mathrm{O}_{5}$ and pure $\mathrm{SrO}$. The phase relations shown in Fig. 1 for $\mathrm{X}_{\mathrm{SrO}}>0.67$ are based on the results obtained in this study; supported by the findings of Abbattista et al. ${ }^{7}$

The compound $\mathrm{Bi}_{2} \mathrm{Sr}_{3} \mathrm{O}_{6}$ decomposes to liquid and $\mathrm{SrO}$ at $1483 \mathrm{~K}^{5}$ There is controversy on the low temperature stability limit of $\mathrm{Bi}_{2} \mathrm{Sr}_{3} \mathrm{O}_{6}$. Conflant et al. ${ }^{2}$ indicate the compound is stable only above $1083 \mathrm{~K}$, whereas Hwang et $a .^{5}$ show the compound to be stable down to $973 \mathrm{~K}$. Abbattista et al. ${ }^{7}$ show the low temperature stability limit as $873 \mathrm{~K}$ in pure $\mathrm{O}_{2}$, but the decomposition 
TABLE I. Crystallographic data on compounds in the system $\mathrm{Bi}-\mathrm{Sr}-\mathrm{O}$.

\begin{tabular}{|c|c|c|c|c|c|c|c|c|}
\hline \multirow[b]{2}{*}{ Compound } & \multicolumn{6}{|c|}{ Lattice parameters } & \multirow[b]{2}{*}{ Structure } & \multirow[b]{2}{*}{ Ref. } \\
\hline & $a(\mathrm{~nm})$ & $b(\mathrm{~nm})$ & $c(\mathrm{~nm})$ & $\alpha$ & $\beta$ & $\gamma$ & & \\
\hline$\alpha-\mathrm{Bi}_{2} \mathrm{O}_{3}$ & 0.5849 & 0.8165 & 0.7510 & & $112.98^{\circ}$ & & Monoclinic, $P 2_{1 / \mathrm{C}}$ & 14 \\
\hline$\delta-\mathrm{Bi}_{2} \mathrm{O}_{3}(T=1047 \mathrm{~K})$ & 0.5660 & & & & & & Cubic, $F m 3 m$ & 14 \\
\hline $\mathrm{SrO}$ & 0.5160 & & & & & & Cubic, $F m 3 m$ & 15 \\
\hline $\mathrm{SrO}_{2}$ & 0.3563 & & 0.6616 & & & & Tetragonal, $I 4 / \mathrm{mmm}$ & 16 \\
\hline $\mathrm{BiSr}_{2}$ & 0.5012 & & 1.7683 & & & & Tetragonal, $\mathrm{I} / \mathrm{mmm}$ & \\
\hline \multicolumn{9}{|c|}{$\beta$-solid solution $\left(\mathrm{X}_{\mathrm{SrO}}=0.4\right)$} \\
\hline \multicolumn{9}{|c|}{$\beta_{2}$} \\
\hline$T=300 \mathrm{~K}$ & 0.3970 & & 2.8540 & & & $120^{\circ}$ & Rhombohedral, $R \overline{3} m$ & 18 \\
\hline$T=600 \mathrm{~K}$ & 0.3983 & & 2.8690 & & & $120^{\circ}$ & Rhombohedral, $R \overline{3} m$ & 18 \\
\hline \multicolumn{9}{|l|}{$\beta_{1}$} \\
\hline$T=1050 \mathrm{~K}$ & 0.4011 & & 2.9011 & & & $120^{\circ}$ & Rhombohedral, $R \overline{3} m$ & 18 \\
\hline \multicolumn{9}{|l|}{$\beta_{2}, \mathrm{X}_{\mathrm{SrO}}$} \\
\hline 0.25 & 0.3976 & & 2.8102 & & & & Rhombohedral, $R \overline{3} m$ & 19 \\
\hline 0.33 & 0.3967 & & 2.8300 & & & & & 19 \\
\hline 0.40 & 0.3968 & & 2.8481 & & & & & 19 \\
\hline $\mathrm{Bi}_{2} \mathrm{SrO}_{4}$ & 1.9300 & 0.4358 & 0.6106 & & $94.80^{\circ}$ & & Monoclinic, $C 2 / m$ & 20 \\
\hline$\gamma$ solid solution & 1.3239 & & 0.4257 & & & & Tetragonal, $I 4 / m$ & 1 \\
\hline \multirow[t]{3}{*}{$\mathrm{Bi}_{2} \mathrm{Sr}_{2} \mathrm{O}_{5}$} & 1.4261 & 0.6160 & 0.7642 & & & & Orthorhombic, Pnma & 21 \\
\hline & 1.4293 & 0.6172 & 0.7651 & & & & Orthorhombic, $P \mathrm{cmm}$ & 1,22 \\
\hline & 1.4307 & 0.6171 & 0.3826 & & & & Orthorhombic, $\mathrm{Cmcm}$ & 4,23 \\
\hline $\mathrm{Bi}_{2} \mathrm{Sr}_{3} \mathrm{O}_{6}$ & 1.2526 & & 1.8331 & & & $120^{\circ}$ & Rhombohedral, $R \overline{3} m$ & 4 \\
\hline $\mathrm{Bi}_{4} \mathrm{Sr}_{6} \mathrm{O}_{15}$ & 1.7236 & 1.7102 & 1.1875 & & & & Orthorhombic & 7 \\
\hline \multirow{4}{*}{$\mathrm{Bi}_{2} \mathrm{Sr}_{6} \mathrm{O}_{11}$} & 1.6933 & & 1.6648 & & & & Tetragonal & 7 \\
\hline & 0.6009 & & 0.8372 & & & & Tetragonal, $I 4 / m$ & 24,25 \\
\hline & 0.6009 & & 5.8663 & & & $120^{\circ}$ & Rhombohedral & 4 \\
\hline & 1.7147 & 1.6758 & 1.6998 & & & & Orthorhombic & 6,26 \\
\hline
\end{tabular}

involves a four-phase equilibrium. ${ }^{7}$ Abbattista et $_{\text {al. }}{ }^{7}$ also suggest the presence of an oxygen-rich compound with the same $\mathrm{Bi} / \mathrm{Sr}$ ratio $\left(\mathrm{Bi}_{4} \mathrm{Sr}_{6} \mathrm{O}_{15}\right)$ which is stable below $\sim 973 \mathrm{~K}$. The formation of this oxygen-rich compound also involves a four-phase equilibrium. The occurrence of two four-phase equilibria in such close proximity is rather unlikely. Hwang et al. ${ }^{5}$ have identified a new compound $\mathrm{Bi}_{2} \mathrm{Sr}_{6} \mathrm{O}_{9}$ which was not detected by Conflant et $a l .{ }^{2}$ The compound has also been identified by Jacob and Mathews ${ }^{8}$ at $1123 \mathrm{~K}$. More recent studies, however, show that this compound has excess oxygen and can be represented as $\mathrm{Bi}_{2} \mathrm{Sr}_{6} \mathrm{O}_{11} \cdot{ }^{7,13} \mathrm{The} \mathrm{Bi} / \mathrm{Sr}$ ratio is identical for both designations. The excess oxygen was detected using TGA and DTA. The compound $\mathrm{Bi}_{2} \mathrm{Sr}_{6} \mathrm{O}_{11}$ was found to decompose to $\mathrm{Bi}_{2} \mathrm{Sr}_{3} \mathrm{O}_{6}, \mathrm{SrO}$, and $\mathrm{O}_{2}$ between $1293 \mathrm{~K}$ and $1363 \mathrm{~K}^{7,13}$ There is a phase transition associated with this compound at $673 \mathrm{~K}^{2}$ The low temperature form appears to have tetragonal symmetry, ${ }^{7,24,25}$ although reported cell parameters show discrepancies. The hightemperature form of $\mathrm{Bi}_{2} \mathrm{Sr}_{6} \mathrm{O}_{11}$ can be quenched to room temperature. At moderate cooling rates both the high and low temperature forms may be present in the sample, making the determination of the correct crystal structure more difficult.

Baek and Virkar ${ }^{27}$ have used galvanic cells with $\mathrm{SrF}_{2}$ solid electrolyte to determine the activity-composition relationship in the system $\mathrm{Bi}_{2} \mathrm{O}_{3}-\mathrm{SrO}$ in the temperature range 850-975 K. Surprisingly, measurements on electrodes with average compositions in the range $0.59<$ $\mathrm{K}_{\mathrm{SrO}}<0.8$ gave approximately the same emf. According to Fig. 1, these compositions should fall in at least two separate phase fields. The emf data of Baek and Virkar ${ }^{27}$ are not sufficient to derive free energies of formation of interoxide compounds. Idemoto et al. $^{28}$ have measured the enthalpies of formation of six compositions which correspond to compounds $\mathrm{Bi}_{2} \mathrm{SrO}_{4}, \mathrm{Bi}_{2} \mathrm{Sr}_{2} \mathrm{O}_{5}, \mathrm{Bi}_{2} \mathrm{Sr}_{3} \mathrm{O}_{6}$, $\mathrm{Bi}_{2} \mathrm{Sr}_{6} \mathrm{O}_{11}$, and solid solutions $\beta$ and $\gamma$. The $\mathrm{Bi}$ ion was found to be in the trivalent state by titration in all the samples. This conflicts with other information which indicates that $\mathrm{Bi}$ is in the pentavalent state in the compound $\mathrm{Bi}_{2} \mathrm{Sr}_{6} \mathrm{O}_{11}{ }^{7,13,29} \mathrm{~A}$ reinvestigation of the ternary system $\mathrm{Bi}-\mathrm{Sr}-\mathrm{O}$, with emphasis on the thermodynamic properties, would be useful to resolve the discrepancies reported in the literature. Phase equilibria under different conditions can be readily computed from the thermodynamic data.

\section{Measurement strategy: Combined use of oxide and fluoride electrolytes}

The activity of $\mathrm{SrO}$ in various phase fields of the system $\mathrm{Bi}-\mathrm{Sr}-\mathrm{O}$ can be measured as a function of temperature using solid-state cells based on $\mathrm{SrF}_{2}$ under controlled partial pressure of oxygen. The electrolyte 
$\mathrm{SrF}_{2}$ is a fluoride ion conductor with transport number $t_{F}-0.99$. The emf of a cell based on $\mathrm{SrF}_{2}$ is directly related to the difference in the chemical potential of $F_{2}$ at the two electrodes. The chemical potential of fluorine is established at each electrode by the exchange reaction,

$$
\mathrm{SrF}_{2}+\frac{1}{2} \mathrm{O}_{2} \longrightarrow \mathrm{SrO}+\mathrm{F}_{2}
$$

where $\mathrm{SrO}$ is present at unit activity at the reference electrode and at reduced activity at the working electrode. To obtain free energies of formation of interoxide compounds from the emf data, Gibbs-Duhem integration across the single-phase field of $\beta$ is necessary. Accurate measurement of the chemical potential of $\mathrm{SrO}$ in singlephase field is rather difficult, since the working electrode in such a case is monovariant. Small perturbations during measurement can cause changes in emf. Higher accuracies are obtained when chemical potentials in two-phase fields are measured under controlled oxygen partial pressure, since equilibria defining potentials at the electrodes are then invariant at constant temperature and total pressure.

Information on oxygen nonstoichiometry or oxygen content of ternary oxides can be obtained by measuring the emf of cells based on $\mathrm{SrF}_{2}$ as a function of oxygen partial pressure at the electrodes at constant temperature..$^{30,31}$ This technique is helpful in determining excess oxygen in some ternary oxides present in the system $\mathrm{Bi}-\mathrm{Sr}-\mathrm{O}$.

In principle, the standard free energy of formation of interoxide compounds can be obtained from measurements of the activity of $\mathrm{Bi}_{2} \mathrm{O}_{3}$ in various phase fields starting from the $\mathrm{SrO}$ side. The accuracy of such measurements decreases as one moves progressively toward compounds richer in $\mathrm{Bi}_{2} \mathrm{O}_{3}$. For example, to obtain the free energy of formation of $\mathrm{Bi}_{2} \mathrm{SrO}_{4}$ at $1050 \mathrm{~K}$, emf of four cells involving phase fields $\mathrm{SrO}+\mathrm{Bi}_{2} \mathrm{Sr}_{3} \mathrm{O}_{6}+\mathrm{Bi}$, $\mathrm{Bi}_{2} \mathrm{Sr}_{3} \mathrm{O}_{6}+\mathrm{Bi}_{2} \mathrm{Sr}_{2} \mathrm{O}_{5}+\mathrm{Bi}, \mathrm{Bi}_{2} \mathrm{Sr}_{2} \mathrm{O}_{5}+\gamma$-phase $+\mathrm{Bi}$, and $\gamma$-phase $+\mathrm{Bi}_{2} \mathrm{SrO}_{4}+\mathrm{Bi}$ have to be combined with the consequent accumulation of errors.

The inaccuracies introduced by Gibbs-Duhem integration across the $\beta$-phase field and combining emf of several cells can be overcome by independent measurements of the activity of both $\mathrm{SrO}$ and $\mathrm{Bi}_{2} \mathrm{O}_{3}$ in two-phase fields using different kinds of solid-state cells. The free energy formation of each ternary oxide lying on the $\mathrm{Bi}_{2} \mathrm{O}_{3}-\mathrm{SrO}$ join can then be obtained from activities of $\mathrm{SrO}$ and $\mathrm{Bi}_{2} \mathrm{O}_{3}$ in two-phase fields on either side of the compound under consideration. For the compound $\mathrm{Bi}_{2 m} \mathrm{Sr}_{n} \mathrm{O}_{3 m+n}$, the standard Gibbs energy of formation from component oxides is given by:

$$
\begin{aligned}
\Delta G_{f, 0 \mathrm{x}}^{0} & =m \Delta \mu_{\mathrm{Bi}_{2} \mathrm{O}_{3}}+n \Delta \mu_{\mathrm{SrO}} \\
& =\mathrm{R} T\left(m \ln a_{\mathrm{Bi}_{2} \mathrm{O}_{3}}+n \ln a_{\mathrm{SrO}}\right),
\end{aligned}
$$

where values for chemical potentials and activities are those in equilibrium with the compound. Two values for the free energy of formation of each compound are obtained when activities of both components are measured in all the two-phase fields of the pseudobinary system $\mathrm{Bi}_{2} \mathrm{O}_{3}-\mathrm{SrO}$, thus providing an independent check on the accuracy of measurements. The standard Gibbs energies of formation of phases that contain excess oxygen and lie above the $\mathrm{Bi}_{2} \mathrm{O}_{3}-\mathrm{SrO}$ join are obtained from measurements on cells based on $\mathrm{SrF}_{2}$, relative to values for $\mathrm{Bi}_{2} \mathrm{Sr}_{3} \mathrm{O}_{6}$ and $\mathrm{Bi}_{2} \mathrm{Sr}_{2} \mathrm{O}_{5}$. Measurements are made on more than the minimum number of cells required to obtain thermodynamic data on compounds and solid solutions, so that the derived information can be cross-checked for internal consistency. For the correct design of galvanic cells, phase relations in the ternary system $\mathrm{Bi}-\mathrm{Sr}-\mathrm{O}$ should be known. Hence, a study of the isothermal section of the phase diagram at $1050 \mathrm{~K}$ is undertaken first.

\section{EXPERIMENTAL}

\section{A. Materials}

Starting materials used for the preparation of interoxide compounds in the system $\mathrm{Bi}_{2} \mathrm{O}_{3}-\mathrm{SrO}$ were fine powders of $\mathrm{Bi}_{2} \mathrm{O}_{3}$ and $\mathrm{SrCO}_{3}$, each of $99.99 \%$ purity, obtained from Johnson Matthey Chemicals Ltd. Anhydrous $\mathrm{SrCO}_{3}$ contained in a platinum crucible was decomposed under vacuum at $1073 \mathrm{~K}$ to $\mathrm{SrO}$. The $\mathrm{SrO}$ thus formed was found to be highly reactive. Fine powders of the component oxides were mixed in appropriate stoichiometric ratio, pelletized at $\sim 20 \mathrm{MPa}$, contained in Pt crucible, and sealed in quartz ampules under reduced pressure of $\sim 2 \times 10^{4} \mathrm{~Pa}$. The ampules were heated at $1073 \mathrm{~K}$ for $\sim 50 \mathrm{~h}$ and at $1173 \mathrm{~K}$ for $\sim 25 \mathrm{~h}$. Formation of interoxide compounds $\mathrm{Bi}_{2} \mathrm{SrO}_{4}, \mathrm{Bi}_{2} \mathrm{Sr}_{2} \mathrm{O}_{5}, \mathrm{Bi}_{2} \mathrm{Sr}_{3} \mathrm{O}_{6}$, $\mathrm{Bi}_{2} \mathrm{Sr}_{6} \mathrm{O}_{11}, \quad \beta$-phase $\left(0.123<\mathrm{X}_{\mathrm{SrO}}<0.423\right)$, and $\gamma$-phase $\left(0.605<\mathrm{X}_{\mathrm{SrO}}<0.635\right)$ was confirmed by $\mathrm{x}$-ray diffraction. The compound $\mathrm{Bi}_{4} \mathrm{Sr}_{6} \mathrm{O}_{15}$ was obtained by heating $\mathrm{Bi}_{2} \mathrm{Sr}_{3} \mathrm{O}_{6}$ in pure oxygen at ambient pressure at $920 \mathrm{~K}$ for $\sim 6 \mathrm{~h}$. The compound $\mathrm{Bi}_{14} \mathrm{Sr}_{24} \mathrm{O}_{52}$ was obtained from component oxides only when heated in pure oxygen at $\sim 1050 \mathrm{~K}$.

Alloys and intermetallic compounds in the system $\mathrm{Bi}-\mathrm{Sr}$ were made by melting or reacting together pure metals in closed iron crucibles under flowing Ar gas. The metals were $99.9 \%$ pure. High purity Ar gas used was dehydrated by passing through anhydrous $\mathrm{MgClO}_{4}$ and $\mathrm{P}_{2} \mathrm{O}_{5}$, and deoxidized by passing through $\mathrm{Cu}$ turnings at $750 \mathrm{~K}$ and $\mathrm{Ti}$ granules at $1150 \mathrm{~K}$.

Optical grade single-crystal $\mathrm{SrF}_{2}$ pellets of $5 \mathrm{~mm}$ thickness and $10 \mathrm{~mm}$ diameter were obtained from Aldrich Chemicals. Yttria-stabilized zirconia crucibles contained approximately $8 \mathrm{~mol} \% \mathrm{Y}_{2} \mathrm{O}_{3}$. High purity $\mathrm{O}_{2}$ gas $(99.999 \%)$ was passed over $\mathrm{CuO}$ at $800 \mathrm{~K}$ to convert 
residual $\mathrm{CO}$ and $\mathrm{H}_{2}$ to $\mathrm{CO}_{2}$ and $\mathrm{H}_{2} \mathrm{O}$, respectively. $\mathrm{CO}_{2}$ was absorbed by passing the gas through $\mathrm{NaOH}$. The gas was subsequently dried by passage through columns containing silica gel, anhydrous $\mathrm{MgClO}_{4}$, and $\mathrm{P}_{2} \mathrm{O}_{5}$. Gas mixtures containing $\mathrm{Ar}$ and $\mathrm{O}_{2}$ were prepared by mixing metered streams of the two gases. Mass-flow controllers were used to meter each gas fed into a mixing tower filled with glass beads.

\section{B. Phase relations in the system $\mathrm{Bi}-\mathrm{Sr}-\mathrm{O}$}

Phase relations at $1050 \mathrm{~K}$ were explored by equilibrating different mixtures of alloys and compounds for $\sim 100 \mathrm{~h}$, followed by quenching in chilled $\mathrm{Hg}$ and phase identification using optical microscopy, XRD, and EDAX. Preliminary experiments indicated that $\sim 60 \mathrm{~h}$ was sufficient to attain equilibrium. Further heat treatment did not change the composition of the samples. Samples containing oxides were held in closed stabilized-zirconia crucibles. Each sample pellet was placed on a small presintered sacrificial pellet of the same composition. The zirconia crucibles were sealed in quartz ampules under a reduced pressure of $\sim 2 \times 10^{4} \mathrm{~Pa}$. Samples containing oxide mixtures were also equilibrated under pure oxygen at a pressure of $1.01 \times 10^{5} \mathrm{~Pa}$ to check for the presence of phases containing excess oxygen. The mass of each sample was determined before and after equilibration. Mixtures containing metallic phase were equilibrated in closed iron containers kept under prepurified inert gas flowing at a rate of $\sim 3 \mathrm{ml} / \mathrm{s}$. Phase composition of quenched samples was determined using XRD, SEM, and EDAX. For accurate determination of composition using EDAX, the electron beam was focused at the center of grains larger than $10 \mu \mathrm{m}$. The composition was found to be invariant across large grains. Different grains belonging to the same phase had identical composition. Pure highdensity pellets of $\mathrm{SrO}$ and $\mathrm{Bi}_{2} \mathrm{O}_{3}$ were used as standards. To check for the attainment of equilibrium, samples of the same overall composition were prepared using different starting materials. Approach to equilibrium was thus verified from different directions.

\section{Emf measurements on cells based on $\left(\mathrm{Y}_{2} \mathrm{O}_{3}\right) \mathrm{ZrO}_{2}$ as the solid electrolyte}

A schematic diagram of the cell used is shown in Fig. 2. The reference electrode consisting of an equimolar mixture of $\mathrm{Bi}$ and $\mathrm{Bi}_{2} \mathrm{O}_{3}$ powders was contained in a stabilized-zirconia crucible with an Os wire embedded in the mixture. The metal Os was found to be inert to liquid $\mathrm{Bi}$ and its oxides. A mixture of $\mathrm{Bi}$ and $\mathrm{Bi}_{2} \mathrm{O}_{3}$ was tightly packed inside the crucible by ramming with a steel rod. The crucible was covered with a stabilizedzirconia lid. The contacting surface of the crucible and the lid were polished using diamond paste. The Os lead

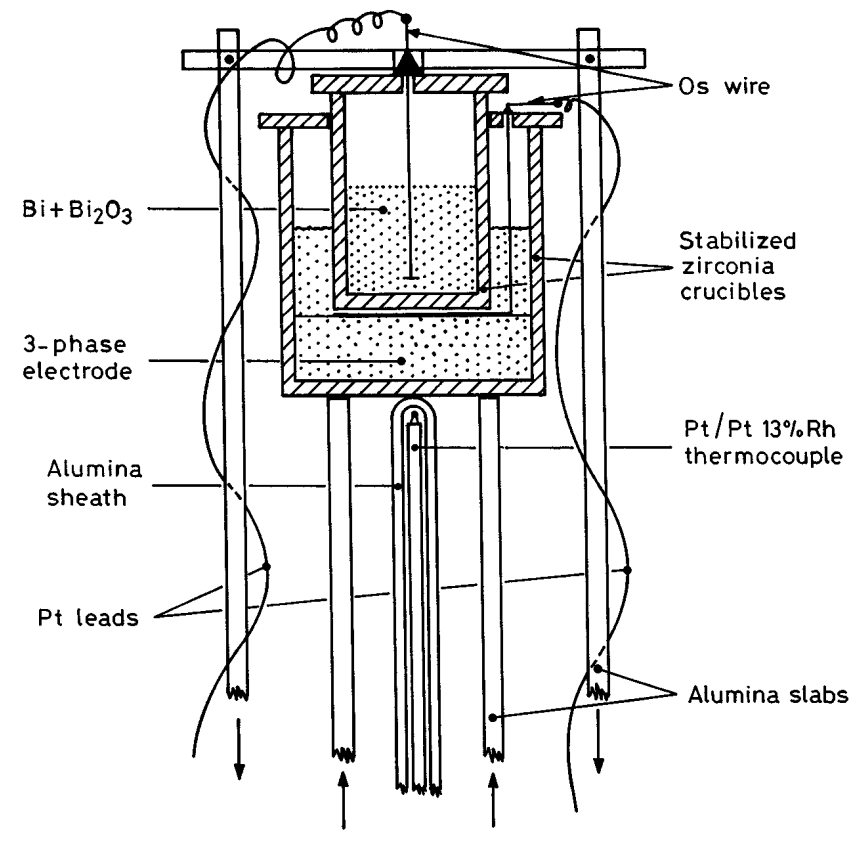

FIG. 2. Schematic diagram of the cell used for emf measurements employing $\left(\mathrm{Y}_{2} \mathrm{O}_{3}\right) \mathrm{ZrO}_{2}$ as the solid electrolyte.

was taken out through a small hole in the lid. The aperture was sealed with a zirconia-based cement.

The working three-phase electrode was contained in a larger zirconia crucible. The electrode was prepared by taking $\mathrm{Bi}$ and two coexisting oxide phases belonging to the pseudobinary system $\mathrm{Bi}_{2} \mathrm{O}_{3}-\mathrm{SrO}$ in the molar ratio $1: 1.5: 1.5$. The mixture was pelletized at $\sim 20 \mathrm{MPa}$ pressure before placing in the zirconia crucible. Although $\mathrm{Bi}$ metal was liquid at the temperatures of measurement, it did not segregate at the bottom of the container. Fine droplets of liquid $\mathrm{Bi}$ in the pellet were held by surface tension forces between surrounding oxide grains. The smaller zirconia crucible containing the reference electrode was pressed down against the three-phase electrode pellet by a system of alumina tubes, slabs, and springs. The annular space between the two zirconia crucibles was packed with the three-phase mixture, composition of which was identical to that of the working electrode. The outer solid electrolyte crucible was also closed with a lid containing a circular hole in the center and an aperture for Os wire contacting the working electrode. The Os wires were connected to Pt leads outside each crucible. Since both Os/Pt junctions were at the same temperature, there was no thermoelectric contribution to the cell emf. The cell assembly shown in Fig. 2 was placed inside a vertical alumina tube and suspended in the even-temperature zone $( \pm 1 \mathrm{~K})$ of a resistance furnace. A stainless steel sheet was wrapped around the alumina tube and earthed to minimize induced emf on cell leads. The top and bottom ends of the vertical alumina tube enclosing the cell were closed with brass 
caps. The brass caps were provided with a gas inlet and outlet and insulated provision for electric leads. The alumina tube was flushed with pre purified Ar gas at a flow rate of $\sim 3 \mathrm{ml} / \mathrm{s}$. The emf developed between the $\mathrm{Pt}$ leads was measured using a high impedance voltmeter. Temperature of the cell was measured by a Pt/Pt-13\% $\mathrm{Rh}$ thermocouple placed adjacent to the zirconia crucible. The temperature was controlled to $\pm 1 \mathrm{~K}$.

The emf of the following cells were measured as a function of temperature:

$$
\begin{array}{r}
\mathrm{Pt}, \mathrm{Os}, \mathrm{SrO}+\mathrm{Bi}_{2} \mathrm{Sr}_{3} \mathrm{O}_{6}+\mathrm{Bi}\left|\left(\mathrm{Y}_{2} \mathrm{O}_{3}\right) \mathrm{ZrO}_{2}\right| \\
\mathrm{Bi}+\mathrm{Bi}_{2} \mathrm{O}_{3}, \mathrm{Os}, \mathrm{Pt}, \\
\mathrm{Pt}, \mathrm{Os}, \mathrm{Bi}_{2} \mathrm{Sr}_{3} \mathrm{O}_{6}+\mathrm{Bi}_{2} \mathrm{Sr}_{2} \mathrm{O}_{5}+\mathrm{Bi}\left|\left(\mathrm{Y}_{2} \mathrm{O}_{3}\right) \mathrm{ZrO}_{2}\right| \\
\mathrm{Bi}+\mathrm{Bi}_{2} \mathrm{O}_{3}, \mathrm{Os}, \mathrm{Pt} \\
\mathrm{Pt}, \mathrm{Os}, \mathrm{Bi}_{2} \mathrm{Sr}_{2} \mathrm{O}_{5}+\mathrm{Bi}_{2} \mathrm{SrO}_{4}+\mathrm{Bi}\left|\left(\mathrm{Y}_{2} \mathrm{O}_{3}\right) \mathrm{ZrO}_{2}\right| \\
\mathrm{Bi}+\mathrm{Bi}_{2} \mathrm{O}_{3}, \mathrm{Os}, \mathrm{Pt},
\end{array}
$$

Pt, Os, $\mathrm{Bi}_{2} \mathrm{SrO}_{4}+\beta$-phase $+\mathrm{Bi}\left|\left(\mathrm{Y}_{2} \mathrm{O}_{3}\right) \mathrm{ZrO}_{2}\right|$

$$
\mathrm{Bi}+\mathrm{Bi}_{2} \mathrm{O}_{3} \text {, Os, Pt. }
$$

The reversibility of emfs was checked by microcoulometric titration in both directions. Emf was found to return to the same value after each titration. The chemical potentials at the electrodes were altered by essentially an infinitesimal amount during each titration. Since the chemical potentials returned to the same value after very small displacements in opposite directions, attainment of equilibrium was demonstrated. Emfs were independent of the flow rate of $\operatorname{Ar}$ gas $(2$ to $5 \mathrm{ml} / \mathrm{s}$ ) around the cell and reproducible on temperature cycling. After each emf run electrodes were examined by x-ray diffraction. No significant change in the phase composition of the electrodes was noted.

\section{Emf measurements on cells based on $\mathrm{SrF}_{2}$ as the solid electrolyte}

A schematic diagram of the cell assembly incorporating $\mathrm{SrF}_{2}$ as the electrolyte is shown in Fig. 3. The electrode pellets were spring-loaded on either side of a transparent single crystal of $\mathrm{SrF}_{2}$, with a thin Pt gauze placed between each electrode and the solid electrolyte. $\mathrm{Pt}$ wires, spot-welded to the Pt gauze on either side of the electrolyte, provided electrical leads to a high impedance voltmeter $\left(10^{13} \Omega\right)$. The pellets were held together under pressure through a system consisting of springs, an alumina rod, and a flat-bottomed alumina tube with a section cut away parallel to its axis as shown in the figure. Direct contact of the electrode pellets with alumina rod or tube was prevented by inserting Pt foils between them. The cell was maintained under dry flowing $\mathrm{O}_{2}$ at a pressure of $1.01 \times 10^{5} \mathrm{~Pa}$.

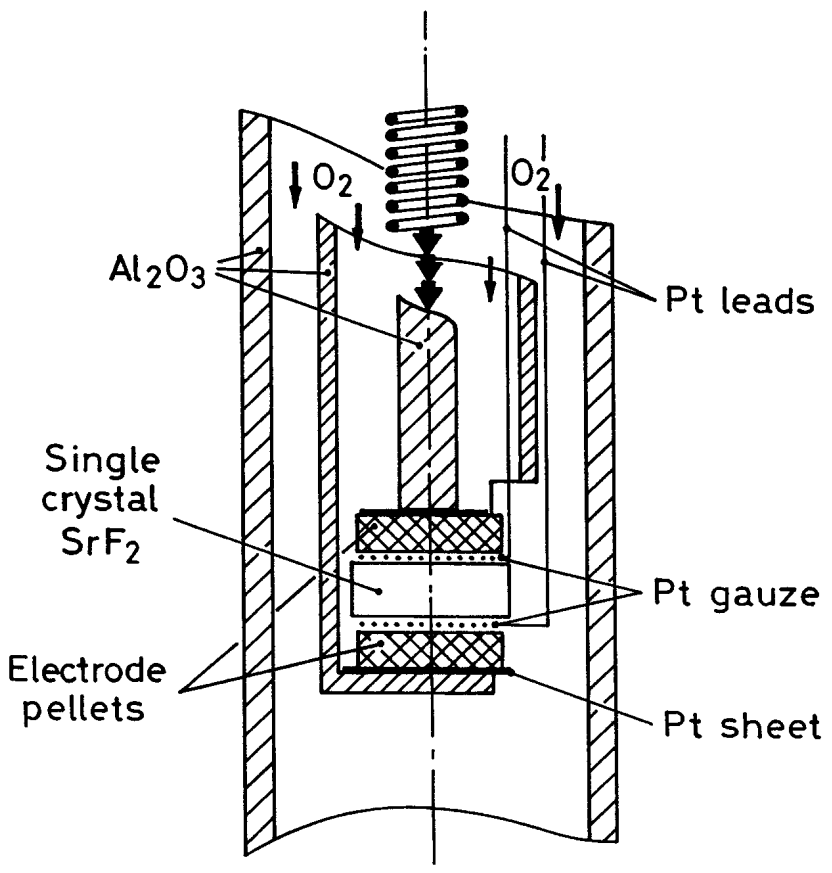

FIG. 3. Schematic diagram of the apparatus used for emf measurements on cells based on single-crystal $\mathrm{SrF}_{2}$ as the electrolyte.

In preliminary experiments, transparent $\mathrm{SrF}_{2}$ crystals were found to become translucent during the run. Fine opaque precipitates appeared on the outer surface of $\mathrm{SrF}_{2}$ crystals. These precipitates were identified by selected area electron diffraction as SrO. They apparently formed by the reaction of the crystal with residual moisture in the gas:

$$
\mathrm{SrF}_{2}(\mathrm{~s})+\mathrm{H}_{2} \mathrm{O}(\mathrm{g}) \longrightarrow \mathrm{SrO}(\mathrm{s})+2 \mathrm{HF}(\mathrm{g}) .
$$

The precipitation of $\mathrm{SrO}$ was minimized by degassing the alumina tubes and rods under vacuum and by using an improved drying procedure for $\mathrm{O}_{2}$ gas. It can be shown from thermodynamic considerations ${ }^{32}$ that $\mathrm{SrF}_{2}$ will not react with dry $\mathrm{O}_{2}$ to form $\mathrm{SrO}$ and $\mathrm{F}_{2}$ at $\left\{\left(P_{\mathrm{F} 2} / P^{0}\right)\right\}>$ $10^{-10}$ unless the chemical potential of $\mathrm{SrO}$ is very low $\left(\Delta \mu_{\mathrm{SrO}}<-360 \mathrm{~kJ} / \mathrm{mol}\right.$ at $\left.1100 \mathrm{~K}\right)$.

The emfs of the following cells were measured as a function of temperature:

$$
\begin{aligned}
& \mathrm{Pt}, \mathrm{O}_{2}, \mathrm{SrO}\left|\mathrm{SrF}_{2}\right| \mathrm{Bi}_{2} \mathrm{Sr}_{6} \mathrm{O}_{11}+\mathrm{Bi}_{2} \mathrm{Sr}_{3} \mathrm{O}_{6}, \mathrm{O}_{2}, \mathrm{Pt}, \\
& \mathrm{Pt}, \mathrm{O}_{2}, \mathrm{SrO}\left|\mathrm{SrF}_{2}\right| \mathrm{Bi}_{2} \mathrm{Sr}_{6} \mathrm{O}_{11}+\mathrm{Bi}_{14} \mathrm{Sr}_{24} \mathrm{O}_{52}, \mathrm{O}_{2}, \mathrm{Pt},
\end{aligned}
$$

Pt, $\mathrm{O}_{2}, \mathrm{SrO}\left|\mathrm{SrF}_{2}\right| \mathrm{Bi}_{2} \mathrm{Sr}_{6} \mathrm{O}_{11}+\mathrm{Bi}_{4} \mathrm{Sr}_{6} \mathrm{O}_{15}, \mathrm{O}_{2}, \mathrm{Pt}$,

Pt, $\mathrm{O}_{2}, \mathrm{SrO}\left|\mathrm{SrF}_{2}\right| \mathrm{Bi}_{2} \mathrm{Sr}_{3} \mathrm{O}_{6}+\mathrm{Bi}_{2} \mathrm{Sr}_{2} \mathrm{O}_{5}, \mathrm{O}_{2}, \mathrm{Pt}$, 


$$
\text { Pt, } \mathrm{O}_{2}, \mathrm{SrO}\left|\mathrm{SrF}_{2}\right| \mathrm{Bi}_{14} \mathrm{Sr}_{24} \mathrm{O}_{52}+\mathrm{Bi}_{2} \mathrm{Sr}_{2} \mathrm{O}_{5}, \mathrm{O}_{2}, \mathrm{Pt}
$$

$$
\mathrm{Pt}, \mathrm{O}_{2}, \mathrm{SrO}\left|\mathrm{SrF}_{2}\right| \mathrm{Bi}_{4} \mathrm{Sr}_{6} \mathrm{O}_{15}+\mathrm{Bi}_{2} \mathrm{Sr}_{2} \mathrm{O}_{5}, \mathrm{O}_{2}, \mathrm{Pt},
$$

$\mathrm{Pt}, \mathrm{O}_{2}, \mathrm{SrO}\left|\mathrm{SrF}_{2}\right| \mathrm{Bi}_{2} \mathrm{Sr}_{2} \mathrm{O}_{5}+\gamma$-phase, $\mathrm{O}_{2}, \mathrm{Pt}$,

Pt, $\mathrm{O}_{2}, \mathrm{SrO}\left|\mathrm{SrF}_{2}\right| \mathrm{Bi}_{2} \mathrm{Sr}_{2} \mathrm{O}_{5}+\mathrm{Bi}_{2} \mathrm{SrO}_{4}, \mathrm{O}_{2}, \mathrm{Pt}$,

$\mathrm{Pt}, \mathrm{O}_{2}, \mathrm{SrO}\left|\mathrm{SrF}_{2}\right| \gamma$-phase $+\mathrm{Bi}_{2} \mathrm{SrO}_{4}, \mathrm{O}_{2}, \mathrm{Pt}$,

$\mathrm{Pt}, \mathrm{O}_{2}, \mathrm{SrO}\left|\mathrm{SrF}_{2}\right| \mathrm{Bi}_{2} \mathrm{SrO}_{4}+\beta$-phase, $\mathrm{O}_{2}, \mathrm{Pt}$,

$\mathrm{Pt}, \mathrm{O}_{2}, \mathrm{SrO}\left|\mathrm{SrF}_{2}\right| \beta$-phase $+\gamma$-phase, $\mathrm{O}_{2}, \mathrm{Pt}$,

$\mathrm{Pt}, \mathrm{O}_{2}, \mathrm{SrO}\left|\mathrm{SrF}_{2}\right| \beta$-phase $+\alpha$-phase, $\mathrm{O}_{2}, \mathrm{Pt}$.

(XVI)

Since $\mathrm{SrO}, \mathrm{SrF}_{2}$, and $\mathrm{O}_{2}$ gas must be in contact to fix the fluorine potential, $\mathrm{SrF}_{2}$ powder was added to $\mathrm{SrO}$ in the preparation of the reference electrode pellet. Similarly, $\mathrm{SrF}_{2}$ was also added to the measuring electrode pellet. Pellets were prepared by mixing component oxides and $\mathrm{SrF}_{2}$ in $1: 1: 0.5$ molar ratio, compacting at $\sim 20 \mathrm{MPa}$ and sintering in prepurified $\mathrm{O}_{2}$ gas. The emf of each cell was first measured as a function of temperature under pure oxygen. Then, the emf was measured as a function of oxygen partial pressure in the gas phase at selected temperatures. The partial pressure was controlled using $\mathrm{Ar}+\mathrm{O}_{2}$ mixtures. In all cases, the same partial pressure of oxygen was maintained at both electrodes.

Each cell exhibited reproducible emfs only in a limited temperature range. The time required to obtain steady emf varied from $\sim 20 \mathrm{~h}$ at $880 \mathrm{~K}$ to $\sim 2 \mathrm{~h}$ at $1200 \mathrm{~K}$. Reversibility of the cells was checked using microcoulometry, temperature cycling, and varying the gas flow rate over the electrodes.

\section{RESULTS AND DISCUSSION}

\section{A. Phase relations}

An isothermal section of the phase diagram of the system $\mathrm{Bi}-\mathrm{Sr}-\mathrm{O}$ at $1050 \mathrm{~K}$ composed from the results of this study is shown in Fig. 4. The bulk compositions of the samples analyzed are shown by cross marks. Twenty-five compositions were analyzed. The hatched composition ranges represent solution phases. All the oxygen-saturated liquid alloys and intermetallic compounds along the binary $\mathrm{Bi}-\mathrm{Sr}$ were found to be in equilibrium with pure SrO. The oxygen solubility in the alloys was negligible. The oxygen chemical potential is expected to increase with concentration of $\mathrm{Bi}$ in the alloy in the two-phase fields involving the alloy and $\mathrm{SrO}$. In three-phase fields, the oxygen potential has to be constant at a fixed temperature according to the phase rule. The compositions of all the compounds and solid solutions were confirmed by EDAX. The information obtained from XRD was consistent with crystallographic data in Table I. The ternary oxides $\mathrm{Bi}_{2} \mathrm{Sr}_{3} \mathrm{O}_{6}, \mathrm{Bi}_{2} \mathrm{Sr}_{2} \mathrm{O}_{5}, \mathrm{Bi}_{2} \mathrm{SrO}_{4}$, and solid solutions $\delta, \beta$, and $\gamma$ were in equilibrium with pure $\mathrm{Bi}$ metal. The $\mathrm{Bi}$ ion was found to be in the trivalent state in these interoxide compounds and solid solutions. It is therefore possible to equilibrate the coexisting phases along the pseudobinary $\mathrm{Bi}_{2} \mathrm{O}_{3}-\mathrm{SrO}$ with metallic $\mathrm{Bi}$ to fix the oxygen chemical potential which can be measured accurately using an oxide electrolyte. The interoxide compounds $\mathrm{Bi}_{2} \mathrm{Sr}_{6} \mathrm{O}_{11}$, $\mathrm{Bi}_{14} \mathrm{Sr}_{24} \mathrm{O}_{52}$, and $\mathrm{Bi}_{4} \mathrm{Sr}_{6} \mathrm{O}_{15}$ were in equilibrium with pure $\mathrm{O}_{2}$ gas. These oxides were not in equilibrium with alloys or intermetallics. The classical iodometric

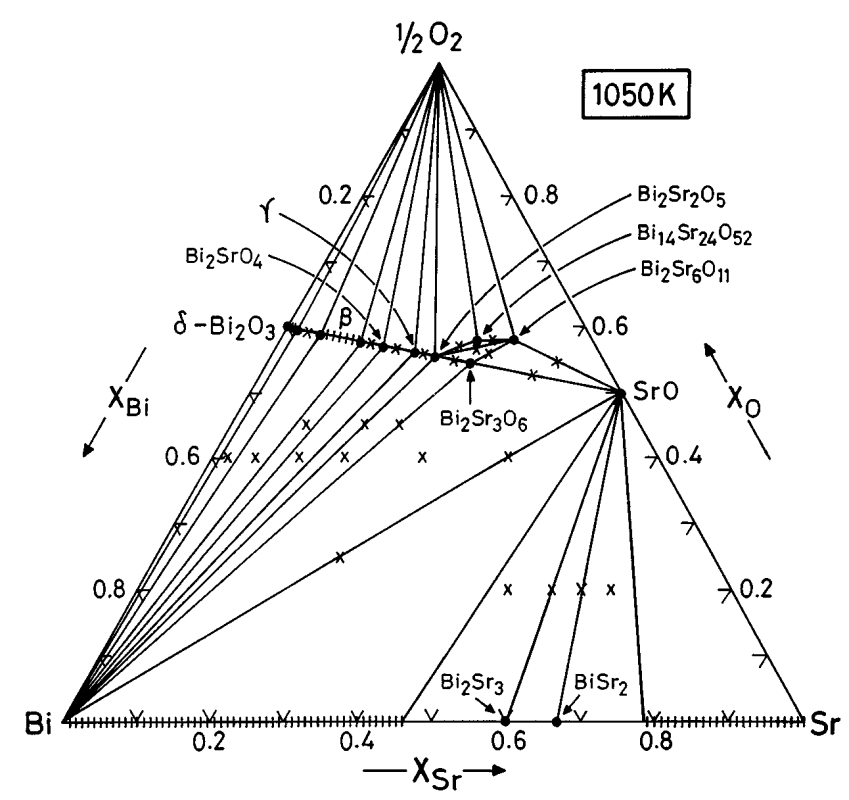

FIG. 4. Isothermal section of the phase diagram for the system $\mathrm{Bi}-\mathrm{Sr}-\mathrm{O}$ at $1050 \mathrm{~K}$ composed from the results of this study. The average composition of sample examined is shown by $\mathrm{X}$. 
method indicated that all the $\mathrm{Bi}$ ions in $\mathrm{Bi}_{2} \mathrm{Sr}_{6} \mathrm{O}_{11}$, $50 \%$ of the $\mathrm{Bi}$ ions in $\mathrm{Bi}_{14} \mathrm{Sr}_{24} \mathrm{O}_{52}$, and $75 \%$ of the $\mathrm{Bi}$ ions in $\mathrm{Bi}_{4} \mathrm{Sr}_{6} \mathrm{O}_{15}$ were pentavalent. The ordering of pentavalent $\mathrm{Bi}$ ions in these structures requires further study. The compound $\mathrm{Bi}_{2} \mathrm{Sr}_{6} \mathrm{O}_{11}$ was found to coexist with $\mathrm{Bi}_{2} \mathrm{Sr}_{2} \mathrm{O}_{5}$ at reduced partial pressure in sealed capsule experiments: $\mathrm{Bi}_{14} \mathrm{Sr}_{24} \mathrm{O}_{52}$ does not coexist with $\mathrm{Bi}_{2} \mathrm{Sr}_{3} \mathrm{O}_{6}$ at $1050 \mathrm{~K}$. Additional information on phase relations and stoichiometry of oxides obtained from emf measurements are discussed in Sec. III. C.

\section{B. Chemical potential of $\mathrm{Bi}_{2} \mathrm{O}_{3}$}

The reversible emfs of cells I to IV are plotted as a function of temperature in Fig. 5. The emfs of cells I to IV exhibit a change of slope at $1003( \pm 1) \mathrm{K}$. This is related to the $\alpha \rightarrow \delta$ transformation of $\mathrm{Bi}_{2} \mathrm{O}_{3}$ in the reference electrode. The average value of the enthalpy of transformation deduced from the change in slope of emf is $30.6( \pm 0.5) \mathrm{kJ} / \mathrm{mol}$ at $1003 \mathrm{~K}$. The emf of cell IV exhibits a second change of slope at $904 \mathrm{~K}$, related to the phase transition of the $\beta$-phase. The enthalpy of transition for the composition $\mathrm{Bi}_{1.16} \mathrm{Sr}_{0.42} \mathrm{O}_{2.16}$ is $8.9( \pm 2) \mathrm{kJ} /$ mol. Within experimental uncertainty limits, the emfs of cells I to IV can be expressed as linear functions of temperature over most of the range, with changes in slope as identified in the figure. The change in slope is due to phase transition of one of the constituents

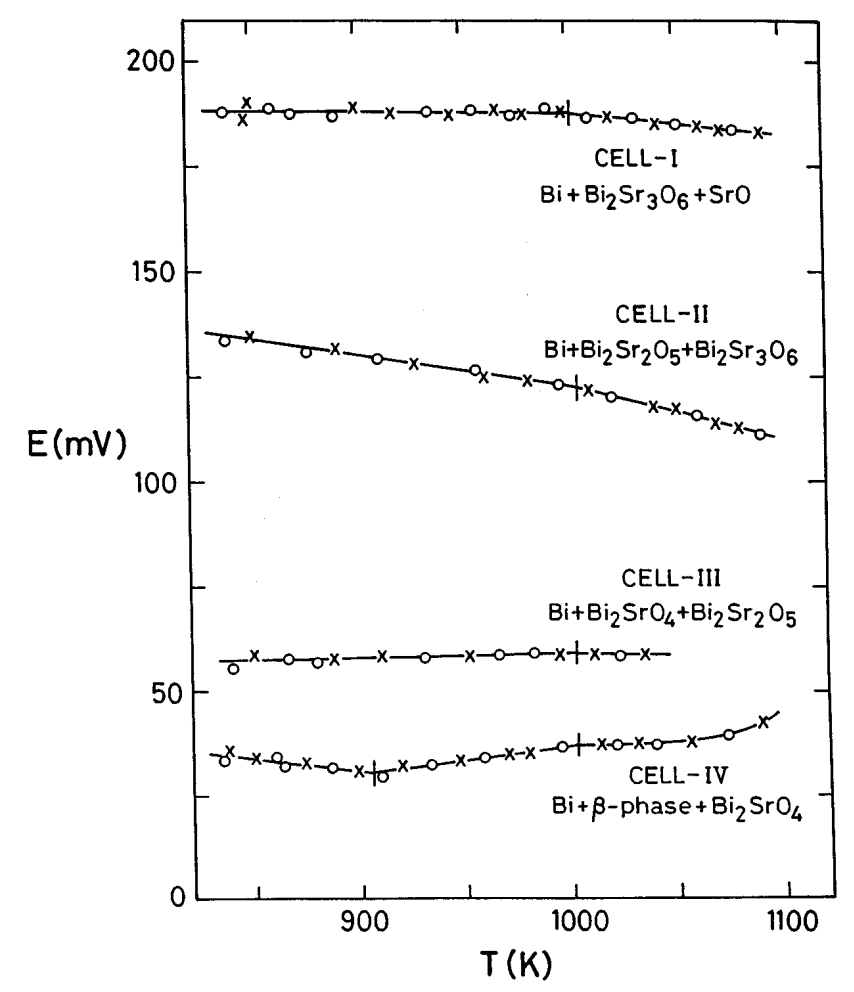

FIG. 5. Emf of cells I to IV based on $\left(\mathrm{Y}_{2} \mathrm{O}_{3}\right) \mathrm{ZrO}_{2}$ as a function of temperature. of the electrodes. Expressions for the emf obtained by a least-squares regression analysis are summarized in Table II. Uncertainty estimates correspond to twice the standard deviation. The emf of cell IV for $T>1050 \mathrm{~K}$ is nonlinear, suggesting that the composition of the $\beta$-phase in equilibrium with $\mathrm{Bi}_{2} \mathrm{SrO}_{4}$ changes rapidly with temperature. The activity or chemical potential of $\mathrm{Bi}_{2} \mathrm{O}_{3}$ in various two-phase fields in the pseudobinary system $\mathrm{Bi}_{2} \mathrm{O}_{3}-\mathrm{SrO}$ can be deduced from the emfs of cells I to IV. The emf is directly related to the chemical potential of $\mathrm{Bi}_{2} \mathrm{O}_{3}$ by the relation,

$$
-6 F E=\Delta \mu_{\mathrm{Bi}_{2} \mathrm{O} 3}=\mathrm{R} T \ln a_{\mathrm{Bi}_{2} \mathrm{O}_{3}} .
$$

The derived chemical potentials relative to $\alpha-\mathrm{Bi}_{2} \mathrm{O}_{3}$ as the reference state are given in Table III.

\section{Chemical potential of SrO}

The variation of emfs of cells $\mathrm{V}$ to $\mathrm{XV}$, operated under pure $\mathrm{O}_{2}$, with temperature is displayed in Fig. 6 . Reproducible emfs were obtained only in a limited temperature range for each cell. This may be related to the instability of one or more phases present at the electrodes. Some evidence for decomposition was obtained from XRD analysis of electrode pellets after emf measurements. The emfs of the cells, except for cells XI and XIV, vary linearly with temperature. The

TABLE II. Emf of cells based on $\left(\mathrm{Y}_{2} \mathrm{O}_{3}\right) \mathrm{ZrO}_{2}$.

\begin{tabular}{ccr}
\hline \hline Cell & $E(\mathrm{mV})$ & Temperature $(\mathrm{K})$ \\
\hline I & $189.5-1.49 \times 10^{-3} T( \pm 1.0)$ & $840-1002$ \\
& $242.2-5.43 \times 10^{-2} T( \pm 0.5)$ & $1002-1090$ \\
II & $197.0-7.40 \times 10^{-2} T( \pm 0.9)$ & $840-1004$ \\
& $249.9-1.27 \times 10^{-1} T( \pm 0.4)$ & $1004-1090$ \\
III & $39.5-2.10 \times 10^{-2} T( \pm 0.9)$ & $840-1002$ \\
& $92.3-3.17 \times 10^{-2} T( \pm 0.3)$ & $1002-1038$ \\
IV & $79.8-5.39 \times 10^{-2} T( \pm 0.8)$ & $840-906$ \\
& $-27.0+6.40 \times 10^{-2} T( \pm 0.5)$ & $906-1002$ \\
& Nonlinear: $37(1020 \mathrm{~K})$, & $1002-1090$ \\
& $37(1040 \mathrm{~K}), 38.3(1060 \mathrm{~K})$, & \\
& $40.5(1080 \mathrm{~K}), 42.5(1090 \mathrm{~K})$ \\
\hline \hline
\end{tabular}

TABLE III. Chemical potential of $\mathrm{Bi}_{2} \mathrm{O}_{3}$ in two-phase fields of the pseudobinary system $\mathrm{Bi}_{2} \mathrm{O}_{3}-\mathrm{SrO}$ relative to $\alpha-\mathrm{Bi}_{2} \mathrm{O}_{3}$.

\begin{tabular}{lc}
\hline \multicolumn{1}{c}{ Phase field } & $\Delta \mu_{\mathrm{Bi}_{2} \mathrm{O}_{3}, \mathrm{~J} / \mathrm{mol}}$ \\
\hline $\mathrm{SrO}+\mathrm{Bi}_{2} \mathrm{Sr}_{3} \mathrm{O}_{6}$ & $-109,715+0.86 T( \pm 580)$ \\
$\mathrm{Bi}_{2} \mathrm{Sr}_{3} \mathrm{O}_{6}+\mathrm{Bi}_{2} \mathrm{Sr}_{2} \mathrm{O}_{5}$ & $-114,060+42.84 T( \pm 520)$ \\
$\mathrm{Bi}_{2} \mathrm{Sr}_{2} \mathrm{O}_{5}+\mathrm{Bi}_{2} \mathrm{SrO}_{4}$ & $-22,870-12.16 T( \pm 520)$ \\
$\mathrm{Bi}_{2} \mathrm{SrO}_{4}+\beta_{2}$ & $-46,190+31.18 T( \pm 470)$ \\
$\mathrm{Bi}_{2} \mathrm{SrO}_{4}+\beta_{1}$ & $15,620-37.04 T( \pm 300)$ \\
& $\{840-1002 \mathrm{~K}\}$ \\
\hline \hline
\end{tabular}




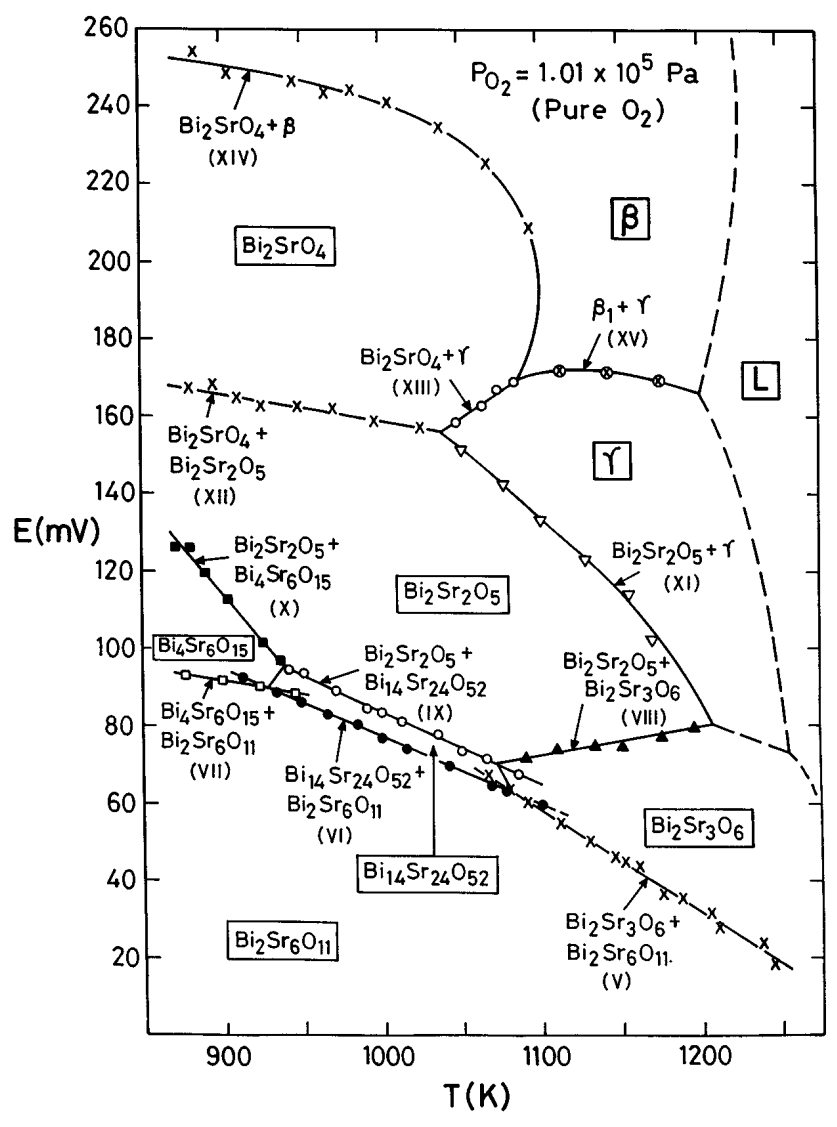

FIG. 6. Emf of cells V to XIV based on $\mathrm{SrF}_{2}$ operated under pure $\mathrm{O}_{2}$ as a function of temperature.

nonlinear variation of the emf of cell XI is probably related to the change in composition of the $\gamma$-phase with temperature. The highly nonlinear variation of the emf of cell XIV above $1000 \mathrm{~K}$ suggests significant change in the composition of $\beta_{1}$-phase with temperature. The results for cell XIV suggest congruent transformation of $\mathrm{Bi}_{2} \mathrm{SrO}_{4}$ to $\beta_{1}$ at $1100( \pm 5) \mathrm{K}$. Emfs of cells $\mathrm{V}$ and VI cross over at $1083( \pm 3) \mathrm{K}$, indicating decomposition of $\mathrm{Bi}_{14} \mathrm{Sr}_{24} \mathrm{O}_{52}$ to $\mathrm{Bi}_{2} \mathrm{Sr}_{3} \mathrm{O}_{6}$ and $\mathrm{Bi}_{2} \mathrm{Sr}_{6} \mathrm{O}_{11}$ at higher temperatures in pure $\mathrm{O}_{2}$. Similarly, emfs of cells VI and VII cross over at $928( \pm 3) \mathrm{K}$, signaling the decomposition of $\mathrm{Bi}_{14} \mathrm{Sr}_{24} \mathrm{O}_{52}$ to $\mathrm{Bi}_{4} \mathrm{Sr}_{6} \mathrm{O}_{15}$ and $\mathrm{Bi}_{2} \mathrm{Sr}_{6} \mathrm{O}_{11}$ in pure oxygen. It is interesting to note that the stable emfs of cells V, VI, and VII are obtained $\sim 20 \mathrm{~K}$ above and below the stability domain of the phases involved. This suggest that metastable equilibrium exists at the electrodes, aided by the slow rate of decomposition of unstable phases. The lower temperature limit for the stability of $\mathrm{Bi}_{2} \mathrm{Sr}_{3} \mathrm{O}_{6}$ is indicated by the intersection of the emfs of cells VIII and IX. Below $1073( \pm 3) \mathrm{K}, \mathrm{Bi}_{2} \mathrm{Sr}_{3} \mathrm{O}_{6}$ decomposes to $\mathrm{Bi}_{14} \mathrm{Sr}_{24} \mathrm{O}_{52}$ and $\mathrm{Bi}_{2} \mathrm{Sr}_{2} \mathrm{O}_{5}$ in pure $\mathrm{O}_{2}$. The compound $\mathrm{Bi}_{4} \mathrm{Sr}_{6} \mathrm{O}_{15}$ decomposes to $\mathrm{Bi}_{2} \mathrm{Sr}_{2} \mathrm{O}_{5}$ and $\mathrm{Bi}_{14} \mathrm{Sr}_{24} \mathrm{O}_{52}$ above $938( \pm 3) \mathrm{K}$ in $\mathrm{O}_{2}$, as suggested by the interaction of the emfs of cells IX and $\mathrm{X}$. The stability fields of $\mathrm{Bi}_{2} \mathrm{Sr}_{6} \mathrm{O}_{11}, \mathrm{Bi}_{2} \mathrm{Sr}_{3} \mathrm{O}_{6}, \mathrm{Bi}_{14} \mathrm{Sr}_{24} \mathrm{O}_{52}$, and $\mathrm{Bi}_{4} \mathrm{Sr}_{6} \mathrm{O}_{15}$ are clearly delineated by the emfs of cells $\mathrm{V}$ to $\mathrm{X}$ in Fig. 6. Phase relations in the ternary system $\mathrm{Bi}-$ $\mathrm{Sr}-\mathrm{O}$ in pure oxygen can be deduced from the emf measurements using cells based on $\mathrm{SrF}_{2}$ as the solid electrolyte. A projection of phase relations in the ternary $\mathrm{Bi}_{2} \mathrm{O}_{3}-\mathrm{SrO}-\mathrm{O}\left(P_{\mathrm{O}_{2}}=1.01 \times 10^{5} \mathrm{~Pa}\right)$ from the oxygen apex on the $\mathrm{Bi}_{2} \mathrm{O}_{3}-\mathrm{SrO}$ isopleath is shown in Fig. 7 for $\mathrm{X}_{\mathrm{SrO}}>0.45$. All the phases in the ternary $\mathrm{Bi}_{2} \mathrm{O}_{3}-\mathrm{SrO}-\mathrm{O}$ in pure oxygen will be seen on the projection. The decomposition temperature of $\mathrm{SrO}_{2}$ is calculated from thermodynamic data. ${ }^{32}$ Clearly, phase relations in pure oxygen are substantially different from that in air (Fig. 1). The compound $\mathrm{Bi}_{14} \mathrm{Sr}_{24} \mathrm{O}_{52}$ has a small stability range in pure oxygen, but is unstable in air. The change in slope of the emf-temperature plot for $\mathrm{Bi}_{2} \mathrm{SrO}_{4}+\mathrm{Bi}_{2} \mathrm{Sr}_{2} \mathrm{O}_{5}$ and $\mathrm{Bi}_{2} \mathrm{SrO}_{4}+\beta$ phase fields (cells XII and XIV, respectively) at $1098 \mathrm{~K}$ is related to phase transition of $\mathrm{Bi}_{2} \mathrm{SrO}_{4}$. The enthalpy of phase transition calculated from emf data is $4.83( \pm 1) \mathrm{kJ} / \mathrm{mol}$.

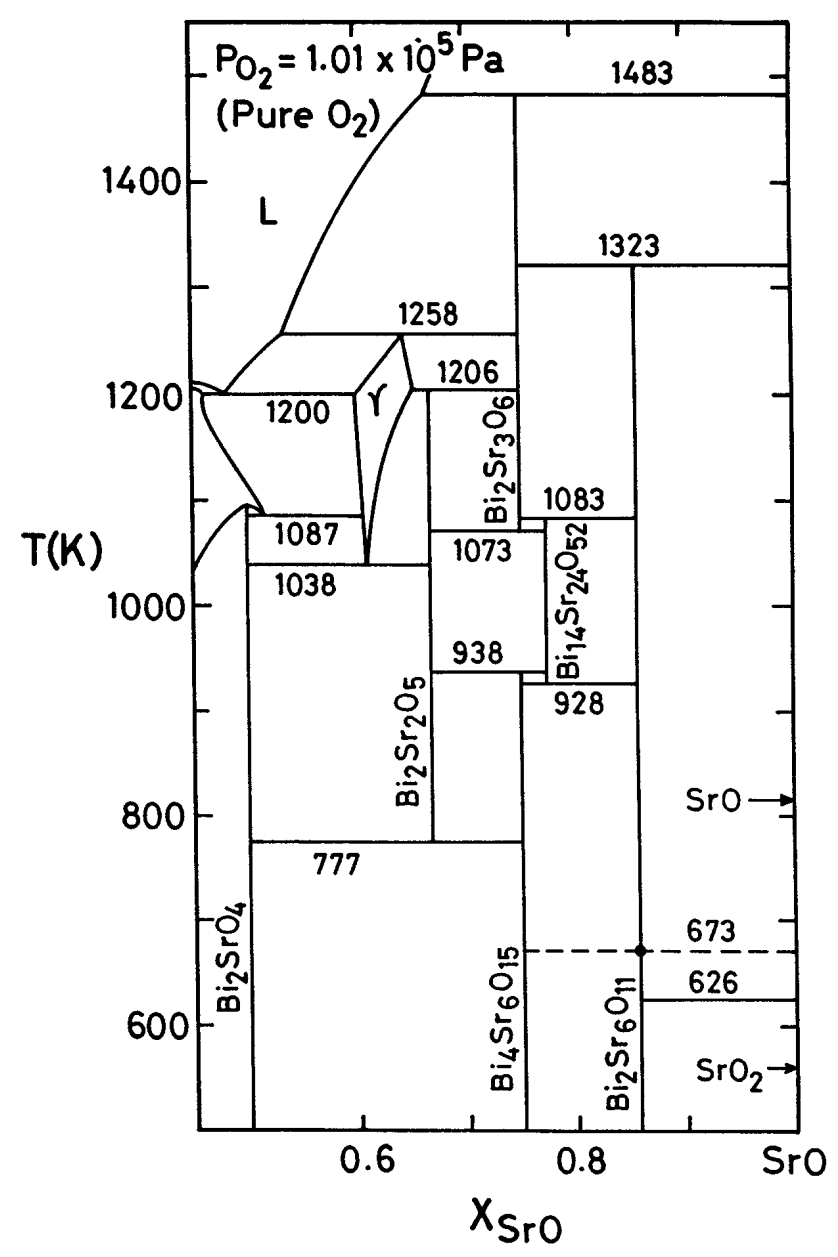

FIG. 7. Projection of phase relations in the system $\mathrm{Bi}_{2} \mathrm{O}_{3}-\mathrm{SrO}-\mathrm{O}$ in pure oxygen at ambient pressure onto the $\mathrm{Bi}_{2} \mathrm{O}_{3}-\mathrm{SrO}$ isopleath. 


\section{Oxygen content of ternary oxides}

If the ternary oxides present at the electrodes exhibit oxygen nonstoichiometry or contain excess oxygen to compensate for the presence of higher valent cations, emfs of cells with fluoride electrolytes will vary with the partial pressure of oxygen over the electrodes..$^{30,31}$ The emfs of cells V, VI, VII, IX, and X were found to be dependent on oxygen partial pressure in the gas phase over the electrodes. The emfs of the other cells incorporating $\mathrm{SrF}_{2}$ were independent of oxygen partial pressure. Figure 8 shows the variation of emf of cell $\mathrm{V}$ with the logarithm of partial pressure at $1150 \mathrm{~K}$. Emf can be represented by the expression,

$$
E=45.02+38.15 \log \left(P_{\mathrm{O}_{2}} / P^{\circ}\right)
$$

where $P^{\circ}$ is the standard atmospheric pressure. The emf is zero when $\log \left(P_{\mathrm{O}_{2}} / P^{\circ}\right)=-1.18$, indicating that $\mathrm{SrO}$ is present as a separate phase at unit activity below this value of partial pressure.

The activity of $\mathrm{SrO}$ at the working electrode of cell $\mathrm{V}$ is defined by the equation:

$$
\mathrm{Bi}_{2} \mathrm{Sr}_{6} \mathrm{O}_{11} \longrightarrow \mathrm{Bi}_{2} \mathrm{Sr}_{3} \mathrm{O}_{6}+3 \mathrm{SrO}+\mathrm{O}_{2} \text {. }
$$

When $\mathrm{Bi}_{2} \mathrm{Sr}_{6} \mathrm{O}_{11}$ and $\mathrm{Bi}_{2} \mathrm{Sr}_{3} \mathrm{O}_{6}$ are present at unit activity, the activity of $\mathrm{SrO}$ at the electrode and hence the emf are functions of the oxygen partial pressure. The

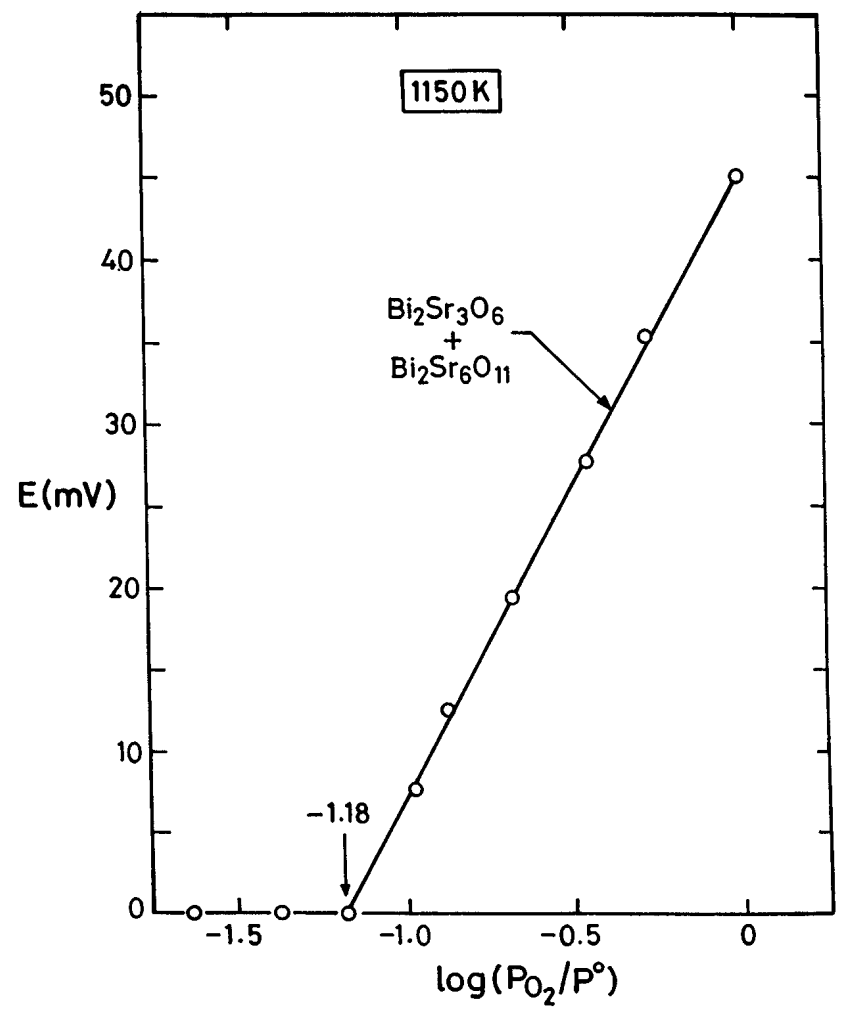

FIG. 8. Variation of the emf of the cell $\mathrm{V}$ with partial pressure of oxygen over the electrodes at $1150 \mathrm{~K} . P^{\circ}=1.01 \times 10^{5} \mathrm{~Pa}$. slope of the line in Fig. 8 is a measure of the number of moles of gaseous oxygen involved in the electrode reaction, which in turn depends on the oxygen content of the ternary oxides. If the oxygen content of $\mathrm{Bi}_{2} \mathrm{Sr}_{6} \mathrm{O}_{11}$ is considered to be unknown, the compound may be represented as $\mathrm{Bi}_{2} \mathrm{Sr}_{6} \mathrm{O}_{9+x}$. Then $\partial E / \partial\left(\log P_{\mathrm{O}_{2}}\right)$ would be given by $(2.303 x \mathrm{RT} / 12 \mathrm{~F})$. The value of $x$ can be determined from the slope of the line in Fig. 8 as 2.007. Thus, the measurement of the emf of cell $\mathrm{V}$ as a function of the oxygen partial pressure confirms the stoichiometry suggested in the literature and the valency of the Bi ion determined by iodometry. Further, the value of partial pressure below which $\mathrm{SrO}$ precipitates as a separate phase can be used to derive the standard free energy change for reaction (6) at $1150 \mathrm{~K}$, and cross-check the free energy data obtained independently.

The variation of the emfs of cells VI and IX with oxygen partial pressure at $1000 \mathrm{~K}$ is displayed in Fig. 9. The emfs of two cells converge at $\log \left(P_{\mathrm{O}_{2}} / P^{\circ}\right)=-0.42$, suggesting decomposition of $\mathrm{Bi}_{14} \mathrm{Sr}_{24} \mathrm{O}_{52}$ to $\mathrm{Bi}_{2} \mathrm{Sr}_{2} \mathrm{O}_{5}$ and $\mathrm{Bi}_{2} \mathrm{Sr}_{6} \mathrm{O}_{11}$ below this partial pressure:

$$
\begin{aligned}
\mathrm{Bi}_{14} \mathrm{Sr}_{24} \mathrm{O}_{52} \longrightarrow & 4.5 \mathrm{Bi}_{2} \mathrm{Sr}_{2} \mathrm{O}_{5} \\
& +2.5 \mathrm{Bi}_{2} \mathrm{Sr}_{6} \mathrm{O}_{11}+\mathrm{O}_{2} .
\end{aligned}
$$

The experimental determination of the partial pressure provides an additional check on the Gibbs energies of formation of the three ternary oxides involved. The activity of $\mathrm{SrO}$ at the working electrodes of cells VI and IX are defined by the equations:

$$
\begin{array}{r}
\mathrm{Bi}_{14} \mathrm{Sr}_{24} \mathrm{O}_{52}+18 \mathrm{SrO}+3.5 \mathrm{O}_{2} \\
\longrightarrow 7_{2} \mathrm{Bi}_{2} \mathrm{Sr}_{6} \mathrm{O}_{11},
\end{array}
$$

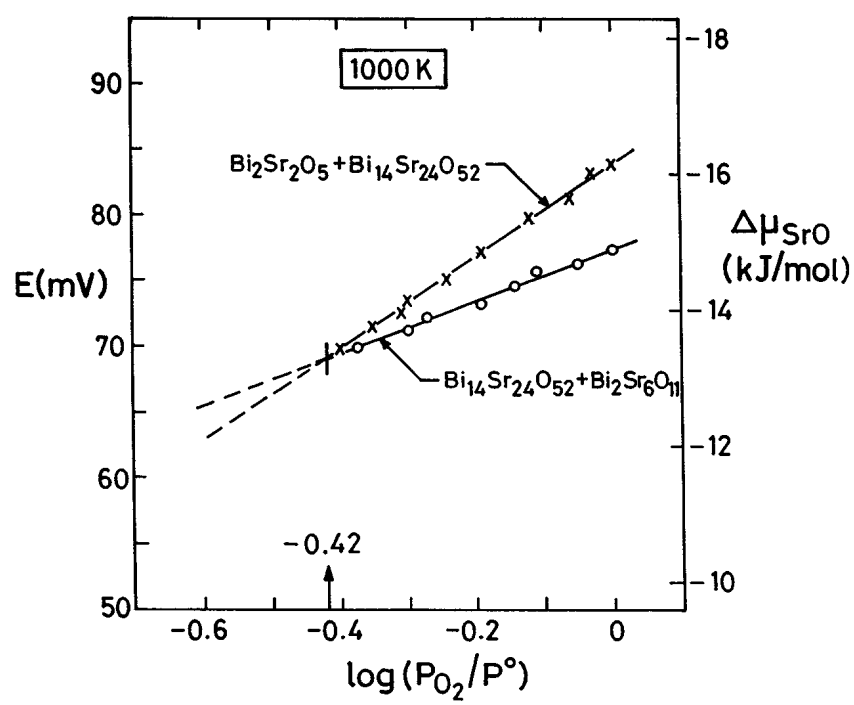

FIG. 9. Variation of emfs of cells VI and IX with partial pressure of oxygen over the electrodes at $1000 \mathrm{~K} . P^{\circ}=1.01 \times 10^{5} \mathrm{~Pa}$. 


$$
\begin{aligned}
\mathrm{Bi}_{14} \mathrm{Sr}_{24} \mathrm{O}_{52} \longrightarrow & 7 \mathrm{Bi}_{2} \mathrm{Sr}_{2} \mathrm{O}_{5} \\
+ & 10 \mathrm{SrO}+3.5 \mathrm{O}_{2},
\end{aligned}
$$

respectively. When the two ternary oxides involved in each reaction are present at unit activity, the activity of $\mathrm{SrO}$ and hence the emf are functions of oxygen partial pressure. The values of $\partial E / \partial\left(\log P_{\mathrm{O}_{2}}\right)$ obtained by experiment are almost identical to values calculated from Eqs. (8) and (9). The oxygen content of $\mathrm{Bi}_{14} \mathrm{Sr}_{24} \mathrm{O}_{52}$ is thus confirmed. Similar studies on the variation of emfs of cells VII and X with oxygen partial pressure confirm the oxygen stoichiometry of $\mathrm{Bi}_{4} \mathrm{Sr}_{6} \mathrm{O}_{15}$.

Expressions for the emf of cells $\mathrm{V}$ and $\mathrm{XV}$ obtained by least-squares regression analysis are given in Table IV. When oxygen at the same partial pressure is present over both the electrodes, the relative chemical potential of $\mathrm{SrO}$ at the working electrode can be directly obtained from the emf of cells incorporating $\mathrm{SrF}_{2}$ as the solid electrolyte:

$$
\Delta \mu_{\mathrm{SrO}}=-2 F E .
$$

Equations for the chemical potential of $\mathrm{SrO}$ deduced from emfs are presented in Table V.

\section{E. Gibbs energies of formation of the interoxide compounds and solid solutions}

The standard Gibbs energies of formation of ternary oxides and solid solutions can be derived from the emf of the various cells. The overall plan of deployment of the emf data for deriving and cross-checking thermodynamic properties of various phases is shown in Fig. 10. The scheme is not unique. Thermodynamic properties of ternary phases can be calculated with slightly reduced

TABLE IV. Emf of cells based on $\mathrm{SrF}_{2}$.

\begin{tabular}{rcr}
\hline \hline Cell & $E(\mathrm{mV})$ & Temperature $(\mathrm{K})$ \\
\hline $\mathrm{V}$ & $344.5-2.60 \times 10^{-1} T( \pm 1.0)$ & $1065-1245$ \\
VI & $251.1-1.74 \times 10^{-1} T( \pm 0.5)$ & $910-1100$ \\
VII & $156.3-7.20 \times 10^{-2} T( \pm 0.5)$ & $875-950$ \\
VIII & $-7.5+7.25 \times 10^{-2} T( \pm 0.6)$ & $1090-1200$ \\
IX & $266.2-1.83 \times 10^{-1} T( \pm 0.6)$ & $940-1090$ \\
X & $556.8-4.93 \times 10^{-1} T( \pm 1)$ & $870-940$ \\
XI & Nonlinear: $142(1077 \mathrm{~K})$, & $1070-1170$ \\
& $133(1101 \mathrm{~K}), 123(1128 \mathrm{~K})$, \\
XII & $114(1155 \mathrm{~K}), 102(1169 \mathrm{~K})$ & \\
XIII & $228.7-7.00 \times 10^{-2} T( \pm 1)$ & $880-1030$ \\
XIV & $-137.0+2.82 \times 10^{-1} T( \pm 0.5)$ & $1040-1087$ \\
& Nonlinear: & $880-1005$ \\
& $234(1038 \mathrm{~K}), 224.5(1068 \mathrm{~K})$, & $T>1005$ \\
XV & $208(1095 \mathrm{~K})$ & \\
& Nonlinear: & $1087-1200$ \\
XVI & $172(1114 \mathrm{~K}), 171(1143 \mathrm{~K})$, & $880-990$ \\
\hline \hline
\end{tabular}

TABLE V. Chemical potential of $\mathrm{SrO}$ in two-phase fields of the system $\mathrm{Bi}-\mathrm{Sr}-\mathrm{O}$ in pure oxygen.

\begin{tabular}{lc}
\hline \hline \multicolumn{1}{c}{ Phase field } & $\Delta \mu_{\mathrm{Bi}_{2} \mathrm{O}_{3}, \mathrm{~J} / \mathrm{mol}}$ \\
\hline $\mathrm{Bi}_{2} \mathrm{Sr}_{6} \mathrm{O}_{11}+\mathrm{Bi}_{2} \mathrm{Sr}_{3} \mathrm{O}_{6}$ & $-66,485+50.18 T( \pm 200)$ \\
$\mathrm{Bi}_{2} \mathrm{Sr}_{6} \mathrm{O}_{11}+\mathrm{Bi}_{14} \mathrm{Sr}_{24} \mathrm{O}_{52}$ & $-48,460+33.58 T( \pm 100)$ \\
$\mathrm{Bi}_{2} \mathrm{Sr}_{6} \mathrm{O}_{11}+\mathrm{Bi}_{4} \mathrm{Sr}_{6} \mathrm{O}_{15}$ & $-30,165+13.90 T( \pm 100)$ \\
$\mathrm{Bi}_{2} \mathrm{Sr}_{3} \mathrm{O}_{6}+\mathrm{Bi}_{2} \mathrm{Sr}_{2} \mathrm{O}_{5}$ & $1450-13.99 T( \pm 120)$ \\
$\mathrm{Bi}_{14} \mathrm{Sr}_{24} \mathrm{O}_{52}+\mathrm{Bi}_{2} \mathrm{Sr}_{2} \mathrm{O}_{5}$ & $-51,375+35.32 T( \pm 120)$ \\
$\mathrm{Bi}_{4} \mathrm{Sr}_{6} \mathrm{O}_{15}+\mathrm{Bi}_{2} \mathrm{Sr}_{2} \mathrm{O}_{5}$ & $-107,460+95.14 T( \pm 200)$ \\
$\mathrm{Bi}_{2} \mathrm{Sr}_{2} \mathrm{O}_{5}+\gamma$-phase & $-27,405(1077 \mathrm{~K})$, \\
& $-25,670(1101 \mathrm{~K})$, \\
& $-23,740(1128 \mathrm{~K})$, \\
& $-22,000(1155 \mathrm{~K})$, \\
$\mathrm{Bi}_{2} \mathrm{Sr}_{2} \mathrm{O}_{5}+\mathrm{Bi}_{2} \mathrm{SrO}_{4}$ & $-19,685(1169 \mathrm{~K})$ \\
$\gamma$ - $\mathrm{phase}+\mathrm{Bi}_{2} \mathrm{SrO}_{4}$ & $-44,140+13.51 T( \pm 200)$ \\
& $26,400-54.42 T( \pm 100)$ \\
$\mathrm{Bi}_{2} \mathrm{SrO}_{4}+\beta$-phase & $\{1040-1087 \mathrm{~K}\}$ \\
& $-64,595+18.01 T( \pm 200)$ \\
& $\{880-1005 \mathrm{~K}\}$, \\
$\beta$-phase $+\gamma$-phase & $-45,160(1038 \mathrm{~K})$, \\
& $-43,330(1068 \mathrm{~K})$, \\
& $-40,140(1095 \mathrm{~K})$ \\
\hline \hline & $-33,195(1114 \mathrm{~K})$, \\
& $-33,000(1143 \mathrm{~K})$, \\
& $-32,810(1075 \mathrm{~K})$ \\
& $-41,530-41.30 T( \pm 400)$ \\
& $\{880-990 \mathrm{~K}\}$ \\
\hline -phase &
\end{tabular}

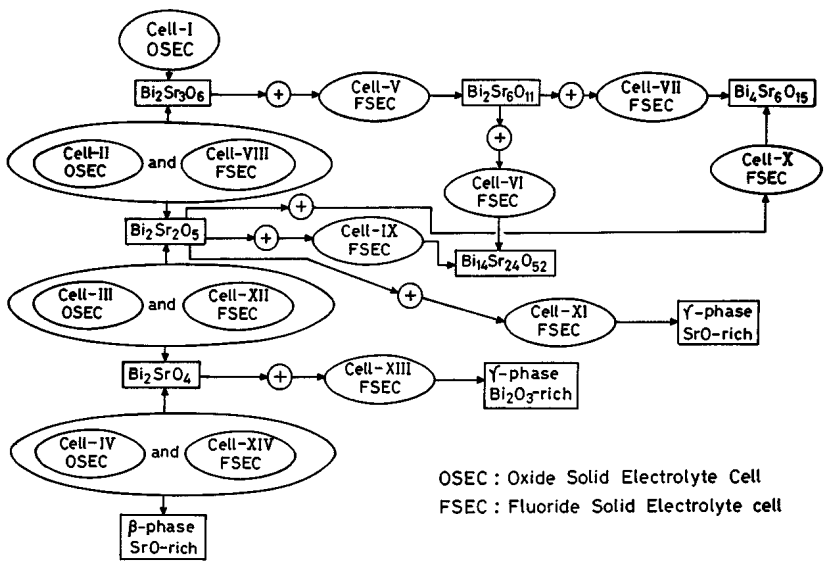

FIG. 10. Plan for the deployment of emf data on various cells for deriving and cross-checking Gibbs energies of formation of ternary oxides and solid solutions. The $\oplus$ sign indicates that Gibbs energy of formation of the preceding phase is combined with measurements on the designated cell to obtain the properties of the following phase on the diagram.

accuracy using other combinations of emfs. The standard Gibbs energy of formation of each ternary oxide on the pseudobinary $\mathrm{Bi}_{2} \mathrm{O}_{3}-\mathrm{SrO}$ join can be computed from the chemical potentials of $\mathrm{Bi}_{2} \mathrm{O}_{3}$ and $\mathrm{SrO}$ in phase fields involving the compound. Thus, two values for the free energy of formation can be derived from chemical potentials of component binary oxides on either side of a ternary compound using Eq. (2). The two values for the Gibbs energy thus derived for each compound are 
found to be in close agreement, indicating good internal consistency. The maximum difference in the value of $\Delta G_{f}^{0}\left(\mathrm{Bi}_{2 m} \mathrm{Sr}_{n} \mathrm{O}_{3 m+n}\right) /(m+n)$ is $350 \mathrm{~J} / \mathrm{mol}$ of component binary oxides. The mean values for the integral free energy of formation of the interoxide compounds and solid solutions are given in Table VI, except for $\mathrm{Bi}_{2} \mathrm{SrO}_{4}$. For this compound, the value obtained from the emf of cells III and XII appear to be more consistent with the properties of the $\gamma$-phase and phase diagram than those derived from the emfs of cells IV and XIV. For the solid solution phases $\beta$ and $\gamma$, only one value is obtained from emf at fixed composition and temperature.

Gibbs energies of compounds containing $\mathrm{Bi}^{5+}$ ions $\left(\mathrm{Bi}_{2} \mathrm{Sr}_{6} \mathrm{O}_{11}, \mathrm{Bi}_{4} \mathrm{Sr}_{6} \mathrm{O}_{15}\right.$, and $\left.\mathrm{Bi}_{14} \mathrm{Sr}_{24} \mathrm{O}_{52}\right)$ are derived relative to those for $\mathrm{Bi}_{2} \mathrm{Sr}_{3} \mathrm{O}_{6}$ and $\mathrm{Bi}_{2} \mathrm{Sr}_{2} \mathrm{O}_{5}$ using emf of cells based on $\mathrm{SrF}_{2}$, as indicated in Fig. 10. The difference between the two sets of values calculated for $\mathrm{Bi}_{4} \mathrm{Sr}_{6} \mathrm{O}_{15}$, according to the scheme in Fig. 10, is $\sim 700 \mathrm{~J} / \mathrm{mol}$; for $\mathrm{Bi}_{14} \mathrm{Sr}_{24} \mathrm{O}_{52}$ the difference is $\sim 2000$ $\mathrm{J} / \mathrm{mol}$. The average values are given in Table VI.

Gibbs energies of formation of ternary phases in the system $\mathrm{Bi}-\mathrm{Sr}-\mathrm{O}$ have not been reported in the literature. However, the chemical potential of $\mathrm{SrO}$ for some compositions has been measured by Baek and Virkar. ${ }^{27}$ Their values are compared with results obtained in this work in Fig. 11. The agreement is satisfactory. Information on standard Gibbs free energies of formation of ternary oxides and solid solutions, obtained for the first time in this study, permit computation of phase diagrams at different oxygen partial pressures. Chemical potential diagrams can also be composed from the present results at different temperatures.

Idemoto et al. ${ }^{28}$ measured enthalpies of formation of five ternary phases at $298 \mathrm{~K}$ by solution calorimetry using $1.53 \mathrm{M} \mathrm{HClO}_{4}$. The "second-law" enthalpies of formation of ternary oxides from binary oxides $\left(\mathrm{Bi}_{2} \mathrm{O}_{3}+\right.$ $\mathrm{SrO}$ ) and $\mathrm{O}_{2}$ (where required) obtained in this study at a mean temperature of $1000 \mathrm{~K}$ are compared with calorimetric information in Table VII. There is good agreement, except for the $\beta$-phase and $\mathrm{Bi}_{2} \mathrm{Sr}_{6} \mathrm{O}_{11}$. Information on the $\beta$-phase obtained in the two studies are for different compositions. The enthalpy of formation of the $\beta$-phase is expected to be a strong function of composition, becoming more negative with $\mathrm{SrO}$ concentration. For the compound $\mathrm{Bi}_{2} \mathrm{Sr}_{6} \mathrm{O}_{11}$, calorimetric data are more negative than the value obtained in this study by $233.3 \mathrm{~kJ} / \mathrm{mol}$. $\mathrm{Bi}^{5+}$ ions were probably present in solution when the compound was dissolved in acid during calorimetric measurement. Hence, by subtracting the enthalpies of solution of $\mathrm{Bi}_{2} \mathrm{O}_{3}$ and $\mathrm{SrO}$ in acid from the enthalpy of solution of the compound, the correct value of enthalpy of formation of the compound would not be obtained. An unknown enthalpy of oxidation of $\mathrm{Bi}^{3+}$ to $\mathrm{Bi}^{5+}$ in solution is required to derive the correct value for the enthalpy of formation of $\mathrm{Bi}_{2} \mathrm{Sr}_{6} \mathrm{O}_{11}$. Incorrect determination of the valency of $\mathrm{Bi}$ in the ternary oxide by Idemoto $e \mathrm{al}^{28}$ led to a faulty calorimetric strategy.

\section{SUMMARY}

An isothermal section of the phase diagram for the system $\mathrm{Bi}-\mathrm{Sr}-\mathrm{O}$ at $1050 \mathrm{~K}$ was established. Several compositions in the ternary were quenched after equilibration, and phases present were identified by optical microscopy, XRD, and EDAX. Five ternary oxides $\left(\mathrm{Bi}_{2} \mathrm{SrO}_{4}, \mathrm{Bi}_{2} \mathrm{Sr}_{2} \mathrm{O}_{5}, \mathrm{Bi}_{2} \mathrm{Sr}_{3} \mathrm{O}_{6}, \mathrm{Bi}_{14} \mathrm{Sr}_{24} \mathrm{O}_{52}\right.$, and $\mathrm{Bi}_{2} \mathrm{Sr}_{6^{-}}$ $\left.\mathrm{O}_{11}\right)$ and three solid solution phases $(\delta, \beta$, and $\gamma)$ were identified at $1050 \mathrm{~K}$. Another ternary compound $\mathrm{Bi}_{4} \mathrm{Sr}_{6} \mathrm{O}_{15}$ was found to be stable at lower temperatures. The presence of pentavalent bismuth was confirmed in compounds $\mathrm{Bi}_{4} \mathrm{Sr}_{6} \mathrm{O}_{15}, \mathrm{Bi}_{14} \mathrm{Sr}_{24} \mathrm{O}_{52}$, and $\mathrm{Bi}_{2} \mathrm{Sr}_{6} \mathrm{O}_{11}$ by iodometry.

Based on the phase diagram, sixteen galvanic cells were designed to measure the activity of $\mathrm{Bi}_{2} \mathrm{O}_{3}$ and $\mathrm{SrO}$ in various phase fields. A yttria-stabilized zirconia solid electrolyte was used to measure the oxygen potential of oxide mixtures in equilibrium with metallic bismuth. A single-crytal $\mathrm{SrF}_{2}$ solid electrolyte was used to measure the activity of $\mathrm{SrO}$ in oxide mixtures under controlled oxygen partial pressures. The emf data allowed independent assessments of the stability of ternary oxides. Data from the different cells were found to be internally consistent. The free energies of formation of ternary phases from the component binary oxides (and oxygen

TABLE VI. Integral molar free energies of formation of interoxide compounds and solid solutions.

\begin{tabular}{llr}
\hline \hline \multicolumn{1}{c}{ Formation reaction } & \multicolumn{1}{c}{$\Delta G_{f}^{0}, J /$ mole } & Temperature $(\mathrm{K})$ \\
\hline$\alpha-\mathrm{Bi}_{2} \mathrm{O}_{3}+3 \mathrm{SrO} \rightarrow \mathrm{Bi}_{2} \mathrm{Sr}_{3} \mathrm{O}_{6}$ & $-109,700+0.86 T( \pm 650)$ & $840-1090$ \\
$\alpha-\mathrm{Bi}_{2} \mathrm{O}_{3}+2 \mathrm{SrO} \rightarrow \mathrm{Bi}_{2} \mathrm{Sr}_{2} \mathrm{O}_{5}$ & $-111,155+14.85 T( \pm 650)$ & $840-1200$ \\
$\alpha-\mathrm{Bi}_{2} \mathrm{O}_{3}+\mathrm{SrO} \rightarrow \mathrm{Bi}_{2} \mathrm{SrO}_{4}$ & $-67,010+1.35 T( \pm 550)$ & $840-1098$ \\
$\alpha-\mathrm{Bi}_{2} \mathrm{O}_{3}+6 \mathrm{SrO}+\mathrm{O}_{2} \rightarrow \mathrm{Bi}_{2} \mathrm{Sr}_{6} \mathrm{O}_{11}$ & $-309,130+151.41 T( \pm 900)$ & $1073-1250$ \\
$2 \alpha-\mathrm{Bi}_{2} \mathrm{O}_{3}+6 \mathrm{SrO}+1.5 \mathrm{O}_{2} \rightarrow \mathrm{Bi}_{4} \mathrm{Sr}_{6} \mathrm{O}_{15}$ & $-437,250+219.8 T( \pm 1900)$ & $870-938$ \\
$7 \alpha-\mathrm{Bi}_{2} \mathrm{O}_{3}+24 \mathrm{SrO}+3.5 \mathrm{O}_{2} \rightarrow \mathrm{Bi}_{14} \mathrm{Sr}_{24} \mathrm{O}_{52}$ & $-1,291,730+456.3 T( \pm 6600)$ & $928-1083$ \\
$0.39 \alpha-\mathrm{Bi}_{2} \mathrm{O}_{3}+0.61 \mathrm{SrO} \rightarrow \mathrm{Bi}_{0.78} \mathrm{Sr}_{0.61} \mathrm{O}_{1.78}(\gamma)$ & $-20,330-11.45 T( \pm 200)$ & $1038-1175$ \\
$0.58 \alpha-\mathrm{Bi}_{2} \mathrm{O}_{3}+0.42 \mathrm{SrO} \rightarrow \mathrm{Bi}_{1.16} \mathrm{Sr}_{0.42} \mathrm{O}_{2.16}\left(\beta_{2}\right)$ & $-26,970-4.14 T( \pm 400)$ & $840-906$ \\
$0.58 \alpha-\mathrm{Bi}_{2} \mathrm{O}_{3}+0.42 \mathrm{SrO} \rightarrow \mathrm{Bi}_{1.16} \mathrm{Sr}_{0.42} \mathrm{O}_{2.16}\left(\beta_{1}\right)$ & $-18,070-13.92 T( \pm 200)$ & $906-1090$ \\
\hline \hline
\end{tabular}




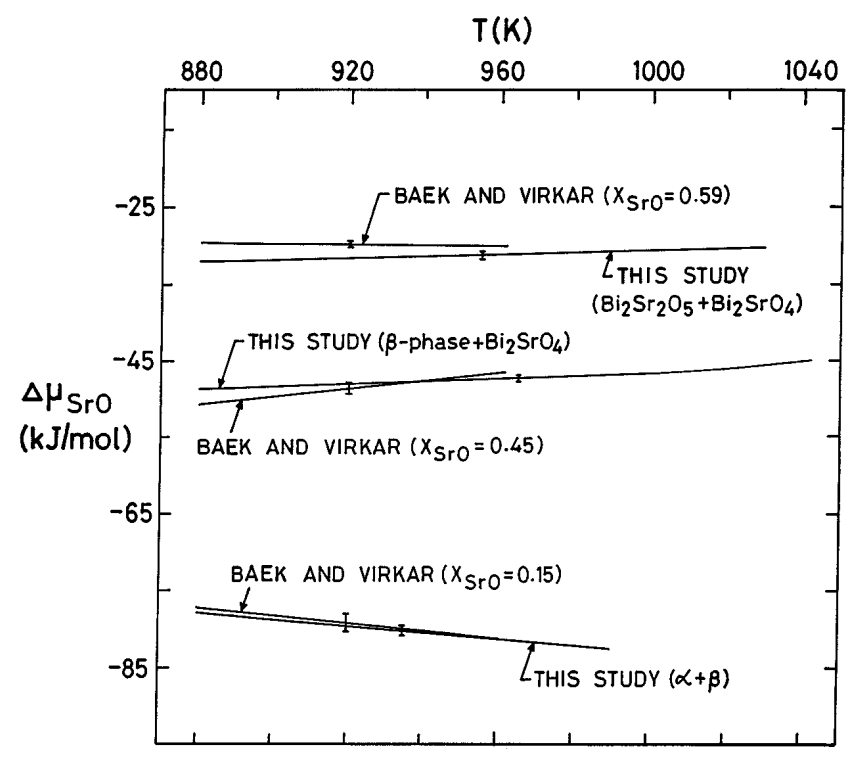

FIG. 11. Comparison of the chemical potential of $\mathrm{SrO}$ obtained in this study with the measurements of Baek and Virkar. ${ }^{27}$

TABLE VII. Comparison of enthalpies of formation of ternary oxides from component binaries (and oxygen) obtained from emf data and calorimetry. ${ }^{28}$

\begin{tabular}{|c|c|c|}
\hline \multirow[b]{2}{*}{ Compound } & \multicolumn{2}{|c|}{$\Delta H_{f}^{0}(\mathrm{~kJ} / \mathrm{mol})$} \\
\hline & This study, emf & Idemoto et al., ${ }^{28}$ calorimetry \\
\hline $\mathrm{Bi}_{2} \mathrm{SrO}_{4}$ & $-67.0( \pm 3)$ & $-62.9( \pm 10.8)$ \\
\hline $\mathrm{Bi}_{2} \mathrm{SrO}_{2} \mathrm{O}_{5}$ & $-111.2( \pm 4)$ & $-115.2( \pm 6)$ \\
\hline $\mathrm{Bi}_{2} \mathrm{Sr}_{3} \mathrm{O}_{6}$ & $-109.7( \pm 5)$ & $-105.0( \pm 12)$ \\
\hline $\mathrm{Bi}_{2} \mathrm{Sr}_{6} \mathrm{O}_{11}$ & $-309.1( \pm 8)$ & $-542.4( \pm 22.4)$ \\
\hline$\gamma$ & $-20.3(+1)$ & $-21.9( \pm 2.7)$ \\
\hline & $\mathrm{X}_{\mathrm{SrO}}=0.61$ & $\mathrm{X}_{\mathrm{SrO}}=0.62$ \\
\hline$\beta_{2}$ & $\begin{array}{l}-26.97( \pm 3) \\
\quad\left(\mathrm{Bi}_{1.16} \mathrm{Sr}_{0.42} \mathrm{O}_{2.16}\right)\end{array}$ & $\begin{aligned}- & 19.04( \pm 3) \\
& \left(\mathrm{Bi}_{1.34} \mathrm{Sr}_{0.33} \mathrm{O}_{2.34}\right)\end{aligned}$ \\
\hline
\end{tabular}

gas) in the temperature range 850 to $1100 \mathrm{~K}$ are given by the following equations:

$$
\begin{aligned}
& \mathrm{Bi}_{2} \mathrm{SrO}_{4}: \quad \Delta G_{f}^{0}(0 \mathrm{x})=-67,020 \\
& +1.35 T \mathrm{~J} / \mathrm{mol} \text {, } \\
& \mathrm{Bi}_{2} \mathrm{Sr}_{2} \mathrm{O}_{5}: \quad \Delta G_{f}^{0}(0 \mathrm{x})=-111,150 \\
& +14.85 T \mathrm{~J} / \mathrm{mol} \\
& \mathrm{Bi}_{2} \mathrm{Sr}_{3} \mathrm{O}_{6}: \quad \Delta G_{f}^{0}(0 \mathrm{x})=-109,700 \\
& +0.86 T \mathrm{~J} / \mathrm{mol} \text {, } \\
& \mathrm{Bi}_{4} \mathrm{Sr}_{6} \mathrm{O}_{15}: \quad \Delta G_{f}^{0}\left(0 \mathrm{x}+\mathrm{O}_{2}\right)=-437,250 \\
& +219.8 T \mathrm{~J} / \mathrm{mol} \text {, } \\
& \mathrm{Bi}_{14} \mathrm{Sr}_{24} \mathrm{O}_{52}: \quad \Delta G_{f}^{0}\left(0 \mathrm{x}+\mathrm{O}_{2}\right)=-1,291,730 \\
& +456.3 T \mathrm{~J} / \mathrm{mol} \text {, } \\
& \mathrm{Bi}_{2} \mathrm{Sr}_{6} \mathrm{O}_{11}: \quad \Delta G_{f}^{0}\left(0 \mathrm{x}+\mathrm{O}_{2}\right)=-309,130 \\
& +151.6 \mathrm{~T} \mathrm{~J} / \mathrm{mol} \text {. }
\end{aligned}
$$

The standard state for $\mathrm{Bi}_{2} \mathrm{O}_{3}$ is the low-temperature crystalline $\alpha$ form. The second law enthalpies of formation of ternary oxides are in good accord with calorimetric information, except for the $\beta$-phase and $\mathrm{Bi}_{2} \mathrm{Sr}_{6} \mathrm{O}_{11}$. The source of the discrepancy for $\mathrm{Bi}_{2} \mathrm{Sr}_{6} \mathrm{O}_{11}$ is identified. Using a novel variation of the galvanic cell technique, in which the emf of a cell incorporating a fluoride electrolyte and oxide electrodes is measured as a function of oxygen potential of the gas phase, oxygen contents of the ternary oxides were confirmed. Improved data obtained in this study can be used to compute phase equilibria in higher order systems as a function of temperature and oxygen partial pressure. Equilibrium phase diagrams are excellent guides for the development and optimization of new processing routes for high $T_{c}$ oxide superconductors.

\section{REFERENCES}

1. R. Guillermo, P. Conflant, J.C. Boivin, and D. Thomas, Rev. Chim. Mineral. 15, 153 (1978).

2. P. Conflant, M. Drache, J. P. Wignacourt, and J. C. Boivin, Mater. Res. Bull. 26, 1219 (1991).

3. E. M. Levin and R. S. Roth, J. Res. Nat. Bur. Stand., Sec. A 68 , 197 (1964).

4. R. S. Roth, C. J. Rawn, B.P. Burton, and F. Beech, J. Res. Natl. Inst. Stand. Technol. 95, 291 (1990).

5. N. M. Hwang, R. S. Roth, and C. J. Rawn, J. Am. Ceram. Soc. 73, 2531 (1990).

6. E. Yu. Vstavskaya, A. Yu. Zuev, V. A. Chereponov, S. D. Sutton, and J. S. Abell, J. Phase Equil. 15, 573 (1994).

7. F. Abbattista, C. Brisi, D. Mazza, and M. Vallino, Mater. Res. Bull. 26, 107 (1991).

8. K. T. Jacob and T. Mathews, J. Mater. Chem. 1, 545 (1991).

9. B. V. Slobodin, I. A. Ostapenko, and A. A. Fotiev, Inorg. Mater. 27, 2220 (1992).

10. K. T. Jacob and K.P. Jayadevan, Mater. Trans. JIM 38, 427 (1997).

11. T. Takahashi, H. I. Iwahara, and Y. Nagai, J. Appl. Electrochem. 2, 97 (1972).

12. M. V. Zinkevich, S. A. Prodan, Yu. G. Zonor, and V. V. Vashuk, Inorg. Mater. 31, 129 (1995).

13. T. Mathews, Ph.D. Thesis, Department of Metallurgy, Indian Institute of Science, Bangalore, India (1993).

14. H. A. Harwig, Z. Anorg. Allg. Chem. 444, 151 (1978).

15. D. Taylor, Trans. J. British Ceram. Soc. 83, 5 (1978).

16. K. J. Range, F. Rau, U. Schiessl, and U. Klement, Z. Anorg. Allg. Chem. 620, 879 (1994).

17. B. Eisenmann and K. Deller, Z. Naturforsch 30B, 66 (1975).

18. D. Mercurio, J.C.C. Mesjard, B. Frit, P. Conflant, J. C. Boivin, and T. Vogt, J. Solid State Chem. 112, 1 (1994).

19. R. L. Withers and H. Rossel, J. Solid State Chem. 118, 66 (1995).

20. T. A. M. Haemers and D. J. W. Ijdo, Mater. Res. Bull. 26, 989 (1991).

21. C. C. Torardi, J. B. Parise, A. Santoro, C. J. Rawn, R. S. Roth, and B. P. Burton, J. Solid State Chem. 93, 228 (1991).

22. P. Conflant and J. C. Boivin, C. R. Acad. Sci., Ser. C., Sci. Chim. 288, 161 (1979).

23. J. F. Vente, R. B. Helmholdt, and D. J. W. Ijdo, Acta Crystallogr. C48, 1380 (1992).

24. Bokhimi and M. Portilla, J. Solid State Chem. 105, 371 (1993). 
25. P. Conflant, M. Drache, M. Lagrenee, J.C. Boivin, and J.P. Wignacourt, Solid State Ionics 53-56, 592 (1992).

26. Y. Ikeda, H. Ito, S. Shimomura, Y. One, K. Inaba, Z. Hiroi, and M. Takano, Physica C 159, 93 (1989).

27. H.D. Baek and A. V. Virkar, J. Electrochem. Soc. 139, 3174 (1992).

28. Y. Idemoto, K. Shizuka, Y. Yasuda, and K. Fueki, Physica C 211, 36 (1993).

29. R. Horyn, M. Wolcyrz, and R. Andruszkiewicz, J. Alloys Compounds 191, 203 (1993).
30. K. T. Jacob and T. Mathews, J. Am. Ceram. Soc. 75, 3225 (1992).

31. T. Mathews, J. P. Hajra, and K. T. Jacob, Chem. Mater. 5, 1669 (1993).

32. M. W. Chase, Jr., C. A. Davies, J.R. Downey, Jr., D. J. Fruip, R. A. McDonald, and A.N. Syverud, Janaf Thermochemical Tables, 3rd ed. J. Phys. Chem. Ref. Data 14, Supplements 1 and 2 (1985). 